\title{
Rômulo Almeida e o Brasil desenvolvimentista (1946-1964): ensaio de reinterpretação *
}

\author{
Alexandre de Freitas Barbosa ** \\ Ana Paula Koury ${ }^{* * *}$
}

\begin{abstract}
Resumo
Este artigo empreende um esforço de reintrepretação sobre o desenvolvimentismo no Brasil. Procura repensá-lo a partir da tríade estruturante que lhe confere sentido: um consenso ideológico sobre as potencialidades nacionais, um estilo de reflexão sobre o país e uma aposta no planejamento democrático e descentralizado. A política econômica é encarada mais como ferramenta do que um fim em si mesmo. Para tanto, acompanhou-se a trajetória Rômulo Almeida, de modo a traçar o pano de fundo do Brasil desenvolvimentista entre 1946 e 1964 . Um esforço de coleta de material inédito produzido pelo economista baiano ao longo dos anos 1970 permitiu mostrar como ele revê sua rica trajetória de servidor público e oferece uma crítica à política econômica da ditadura militar, partindo de um pensamento sistêmico e de uma dialética planejadora. Ao final, são tecidas algumas considerações acerca das possibilidades de emergência de uma nova perspectiva desenvolvimentista para o país no contexto atual.
\end{abstract}

Palavras-chave: Desenvolvimentismo; Teoria do subdesenvolvimento; Nacionalismo; Burocracia; Planejamento.

\begin{abstract}
Rômulo Almeida and developmentalist Brazil (1946-1964): a reinterpretarion

This paper presents a different approach toward the understanding of developmentalism in Brazil. The intention is to shed light on this process through its three distinct aspects: an ideological consensus on national potential, a methodological apparatus for interpreting the social and economic structures of the country, and a belief on a decentralized and democratic style of State planning. In this regard, economic policy is seen rather as a means than as an end in itself. To accomplish this task, Rômulo Almeida's career within state bureaucracy was studied, which makes it possible to interpret the debate around development in Brazil between 1946 and 1964 from a different perspective. The article is the result of a research effort that revealed new documents produced by the author, especially in the 1970's, in which he not only reconsiders his rich trajectory, but also offers a critical approach toward the economic policies put into place by military governments. At the end of this paper, some possibilities for awakening new perspectives on development in present-day Brazil are taken into account.
\end{abstract}

Keywords: Developmentalism. Underdevelopment theory. Nationalism. Bureaucracy. Planning. JEL B30, B31, N66, N96, O18.

${ }^{*}$ Versão bastante resumida do relatório preliminar Rômulo Almeida e as Bases Econômicas e Institucionais para o Desenvolvimento da Nação apresentado como parte da pesquisa realizada no âmbito do Programa Cátedras Ipea/Capes para o Desenvolvimento, de dezembro de 2010 a março de 2012. Muitas destas ideias ainda estão em fase de lapidação, pois a consulta e interpretação do material coligido sobre e de Rômulo Almeida ainda se encontram em fase de finalização.

** Professor de História Econômica e Economia Brasileira do Instituto de Estudos Brasileiros da Universidade de São Paulo (IEB/USP), São Paulo, SP, Brasil. Email: afbarbosa@usp.br.

**** Professora do Programa de Pós-Graduação em Arquitetura e Urbanismo da Universidade São Judas Tadeu (USJT), São Paulo, SP, Brasil. Email: apkoury@gmail.com. 


\section{Introdução}

Para além de analisar a contribuição de Rômulo Almeida para a prática e o pensamento desenvolvimentistas, predominantes durante o período 19461964, procurou-se, neste artigo, partindo da experiência do economista baiano como servidor público e dos textos que produziu - a maioria dos quais inéditos -, reinterpretar o próprio conceito que costuma dar nome a um período da história econômica brasileira.

A trajetória de Rômulo permite devolver ao conceito o vigor encoberto pelas camadas sucessivas de interpretações que recebeu nos últimos três decênios. Ocupando lugares estratégicos no serviço público durante os cerca de 40 anos que se seguem a seu ingresso no DASP, em 1944; Rômulo realiza um constante esforço para compreender a situação brasileira em uma perspectiva coerente, crítica e enraizada na circunstância histórica, lançando luz sobre as mudanças econômicas e os conflitos sociais e políticos que acometeram o país neste tempo curto acelerado. Paralelamente, desenvolve uma explicação e uma alternativa para o Brasil.

Vale lembrar que Rômulo e os demais economistas de sua geração - como Celso Furtado, Ignacio Rangel e até mesmo o Roberto Campos da primeira metade dos anos 50 - não se diziam desenvolvimentistas, mas sim, nacionalistas. Teorizavam sobre o potencial produtivo da nação, a partir de uma ótica que transcendia o terreno econômico, para abarcar suas relações com a sociedade, política e cultura. Atuavam no sentido de alargar as estruturas sociais para permitir que o desenvolvimento tal como o interpretavam - pudesse integrar o território, gestando uma nação mais "homogênea" e menos desigual.

Assim, o consenso desenvolvimentista estava atado a um projeto de nação, que começa a esgarçar-se com o golpe militar de 1964. As noções de milagre econômico e de Brasil potência servem para validar um novo acordo de classes e como horizonte simbólico para as novas elites que passaram a comandar o país nos anos 1970. Por mais que o Estado seguisse atuante e caminhasse para a diversificação produtiva e à defesa do mercado interno, os novos compromissos de classe apontam para uma alteração de sentido do padrão de desenvolvimento capitalista, o que inviabiliza o enquadramento do período no perímetro do desenvolvimentismo. No máximo, um pós-desenvolvimentismo e apenas quando comparado aos vizinhos sulamericanos que perseguiram caminhos radicalmente opostos.

O "pós-desenvolvimentismo" seria sucedido pelo não desenvolvimentismo durante as últimas duas décadas do século XX, já que as preocupações com a estabilização monetária e depois, com uma nova inserção internacional, articulariam o novo acordo de classes que passaria a definir os destinos do país no sentido da 
sua desnacionalização. Na época, falava-se de "inserir o país na globalização", formulação aparentemente ingênua, pois ocultava o fato de que o Brasil sempre estivera inserido de maneira subordinada e periférica na economia-mundo capitalista, embora sob formas diversas.

Supõe-se, portanto, que o desenvolvimentismo, mais do que um conjunto de políticas econômicas aplicadas em determinado período histórico, refere-se a um consenso ideológico sobre determinados objetivos sociais e políticos que as informava e lhes dava (ou retirava) sentido. Estava ainda associado a um estilo de reflexão - herdeiro da primeira Cepal e desenvolvido mais especificamente por Furtado, por meio do método histórico-estruturalista - e a uma concepção de planejamento democrático e redutor das desigualdades presente nesses construtores de instituições.

O objetivo é recuperar o Brasil desenvolvimentista de Rômulo Almeida, quando ele e seus colegas de missão procuraram erguer os alicerces sociais e econômicos ancorados na ideologia de uma civilização brasileira, processo desvirtuado pelo regime militar e, depois, abandonado pelas elites que não só comandaram o processo de abertura econômica, como também intentaram brecar parcela importante dos avanços sociais definidos pela Constituição de 1988.

Daí a necessidade de se distinguir entre o consenso ideológico predominante no período 1946-1964, as políticas de desenvolvimento (e não apenas as econômicas) adotadas e as ferramentas teóricas utilizadas por muitos dos economistas pensadores desenvolvimentistas. Distinguir para revelar sua identidade histórica comum. O desenvolvimentismo é feito dessa tríade poderosa. Sem um de seus componentes, ele aparece como farsa ou mito. O marco inicial situa-se em 1946, quando várias das instituições estatais já haviam sido criadas, ao mesmo tempo em que se abriam novas potencialidades de gestão democrática no país. É, no citado momento, também, apesar do interregno liberal do Governo Dutra, que os desenvolvimentistas passaram a intervir de maneira decisiva e articulada no aparelho estatal.

Vale lembrar que os principais pensadores desenvolvimentistas nacionalistas não apoiaram as políticas econômicas dos regimes militares. Além de combaterem os novos tecnocratas empossados - possuíam severas críticas mesmo aos governos de JK e de João Goulart -, partiam de um referencial teórico que seria paulatinamente abandonado a partir dos anos 1970, inclusive por segmentos da esquerda acadêmica. O resgate da tríade poderosa - consenso ideológico, política de desenvolvimento (para além da política econômica) e abordagem teórica original sobre o subdesenvolvimento - é condição essencial a fim de que se avance para além do pré-desenvolvimentismo inaugurado com o Governo Lula.

O presente artigo encontra-se dividido em três partes: 1. A trajetória de 
Rômulo Almeida; 2. Rômulo Almeida e o Brasil Desenvolvimentista (1946-1964); 3. Os Anos 1970: Desilusão, Combate e a Dialética Planejadora, às quais se seguem as considerações finais.

Boa parte do presente texto encontra-se baseado em material não publicado por Rômulo Almeida ${ }^{1}$ - discursos, palestras, entrevistas e artigos para jornal e revistas - e coletado junto ao Instituto Rômulo Almeida de Altos Estudos (IRAE), em Salvador e no Centro de Pesquisa e Documentação de História Contemporânea do Brasil (CPDOC), no Rio e Janeiro, que abriga o acervo de Jesus Soares Pereira, outro desenvolvimentista ilustre, assim como Rômulo, um ilustre desconhecido das novas gerações.

\section{A trajetória de Rômulo Almeida}

A reflexão de Rômulo Almeida é fruto de sua inserção muito peculiar na história do país durante o período analisado. Sob uma forte influência positivista, tornar-se-ia nacionalista ferrenho, chegando a juntar-se às integralistas, pois as ideias do PCB lhe pareciam "importadas". Nascido na Bahia, chega à capital federal em 1933. Zanza de um emprego a outro, sendo preso no Rio logo quando do Estado Novo. Passa os anos 1940-1941 no Acre, como Diretor do Recenseamento Geral no Território, até ser aprovado por concurso no DASP em 1944. Começa sua carreira de servidor trabalhando no Ministério do Trabalho, Indústria e Comércio, quando redige parecer favorável ao relatório de Roberto Simonsen, propondo o planejamento estatal no país. Integra várias comissões e participa como delegado brasileiro da primeira reunião do GATT em 1947. Organiza a partir de 1948 o Departamento Econômico da CNI, quando escreve seus primeiros artigos sobre a economia brasileira.

Filia-se ao PTB em 1950, criticando o personalismo do partido, mas opondose à alternativa udenista com a qual flertara no passado, em busca da democratização do país. Como assessor Econômico de Vargas, de 1951 a 1954, cria com sua equipe de "boêmios cívicos" instituições como a Petrobras, os planos que servem de embrião para a futura Eletrobrás, o Banco do Nordeste do Brasil - do qual se torna o primeiro presidente -, além de participar diretamente do Plano Nacional do Carvão, da redação do projeto da Superintendência do Plano de Valorização Econômica da Amazônia (SPVEA), da Comissão Nacional de Política Agrária e Comissão de BemEstar Social. Inaugura o planejamento sistemático em nível estadual no país como secretário da Fazenda da Bahia na segunda metade dos anos 1950. Torna-se ainda defensor da integração latino-americana, em virtude de sua atuação como secretáriogeral da Área Latino-Americana de Livre Comércio (ALALC) e como membro do Comitê dos 9 da OEA, cargos ocupados entre 1961 e 1966.

(1) Esse apelido é conferido por Vargas à equipe da sua Assessoria Econômica. Ver Rangel, Ignácio. Especial para a Folha de São Paulo (Almeida, 1995, p. 79). 
Durante o período militar, atua a partir de sua empresa de consultoria - Consultoria e Planejamento S.A. (CLAN S.A.) - ao elaborar projetos para o desenvolvimento econômico da Bahia, funcionando como uma espécie de servidor público exilado no setor privado. O Centro Industrial de Aratu e o Pólo Petroquímico de Camaçari surgiram de projetos por ele arquitetados, junto de sua equipe, ainda que tais iniciativas não tenham levado em consideração todas as recomendações. Nos anos 1970, firma-se como economista crítico ao regime militar, ao mesmo tempo em que é consultado de maneira informal sobre os projetos estruturantes d o II PND, já no governo Geisel. Seu último posto seria o de Diretor da Área Industrial do Banco Nacional de Desenvolvimento Econômico e Social (BNDES), durante o Governo Sarney, cargo que exerce quando morre subitamente em 1988.

Participa do processo de redemocratização como importante quadro do antigo Movimento Democrático Brasileiro (MDB). Diferentemente dos colegas mais próximos, segue uma carreira política paralela. Além de deputado federal eleito em 1954, é lançado como candidato a vice-governador da Bahia em 1958 e como senador de seu estado em 1978, eleições que viria a perder. Foi ainda convidado por JK a assumir o Ministério do Trabalho e por Geisel a se filiar à Arena, convites os quais recusa. Tal fato revela o apreço de que gozava como técnico do setor público, mesmo para governos com orientações políticas divergentes, ainda que jamais se mostrasse neutro quanto a seu posicionamento ideológico.

Em virtude dessa trajetória peculiar, tornou-se profundo conhecedor da realidade brasileira, do processo político e de suas instituições, o que lhe permitiu construir uma abordagem coerente e sistêmica do problema social brasileiro, na qual articulou economia, cultura e território nas escalas regional, nacional e internacional.

Entre os artigos que tratam do desenvolvimento econômico, o problema regional aparece como estratégico, adquirindo uma função integradora da nação. Segundo suas palavras, decifrar o "enigma baiano" seria enfrentar o desafio da problemática brasileira (Almeida, s.d. a).

As desigualdades sociais são provenientes de dinâmicas específicas nas regiões "atrasadas", portanto devem ser combatidas por meio de ações também localizadas espacialmente. Essa forma de conceber o planejamento econômico, partindo de uma perspectiva totalizante, sem deixar de conferir especial importância à dimensão territorial do desenvolvimento, a qual se mostra profundamente diversa nas áreas rurais e urbanas e conforme a região do país aparece como uma das marcas de Rômulo (Almeida, 1975b, p. 21).

Rômulo Almeida, com certeza, não surgiu do vácuo. Ele é parte de uma conjuntura histórica que produziu intelectuais comprometidos como Celso Furtado, 
Ignacio Rangel e Jesus Soares Pereira, para mencionar apenas seus conterrâneos nordestinos, todos eles economistas formados essencialmente no e para o setor público. Personagens, também, como Darcy Ribeiro e Helio Jaguaribe - este último, fundador com Rômulo do Grupo de Itatiaia, depois IBESP, que desembocaria no ISEB - dentre tantos outros.

Seus grandes mentores intelectuais diretos foram Roberto Simonsen, San Thiago Dantas, Josué de Castro e Anisio Teixeira, o que revela a amplitude da percepção sobre o processo de desenvolvimento. Sua contribuição particular está na organização de um sistema de planejamento orientado centralmente, cuja estratégia de "enraizamento" realizar-se-ia a partir de instituições locais adequadas à realidade brasileira.

\section{Rômulo Almeida e o Brasil desenvolvimentista (1946-1964)}

Durante o citado período, Rômulo inscreveria sua marca no território nacional. É difícil abrir o mapa do país de hoje, o organograma das agências estatais, várias iniciativas empresariais e projetos sociais sem se deparar com o fantasma de Rômulo a perscrutar os economistas dos anos 2000 de maneira humilde e bonachona. Ele não esconderia, entretanto, certa amargura pelo que poderia ter sido, pois a construção seria "interrompida" tal como sintetizara seu amigo Celso Furtado todo o sentimento de uma geração.

Rômulo fora um ser quase onipresente no aparelho do Estado que então se consolidava, ainda que apareça ofuscado, ocupando intermináveis notas de rodapé nas obras que tratam dos 20 anos que antecedem o golpe militar. Não nos parece que tal esquecimento seja algo deliberado, devendo jogar-se a culpa nos ideólogos do Brasil potência, nos neoliberais que vieram depois ou, quem sabe, na comunidade dos historiadores econômicos. Todos, é certo, têm sua parcela de responsabilidade. Parece, contudo, até lógico que Rômulo ficasse soterrado na medida em que se extinguia a utopia nacional. Em decorrência desta profunda identidade, qualquer resgate do desenvolvimentismo no Brasil de hoje deve passar por uma redescoberta de seu pensamento e de uma reinterpretação do legado de sua geração.

É importante direcionar a máquina do tempo para esse baiano, servidor público abnegado, que muito aprendera no convívio com Roberto Simonsen e San Tiago Dantas e inspirara-se na ideia de nação contida nas obras de Alberto Torres e Euclides da Cunha. Ele respirara política, participando de todos os movimentos dos anos 30, na ânsia de construir um país moderno e justo e agora se vê guindado ao posto de principal técnico do segundo Governo Vargas.

Dia 11 de fevereiro de 1951, data em que o personagem recebe a incumbência de redigir a Mensagem Presidencial de Vargas para o Congresso. O prazo para sua 
entrega é o dia 15 de março (Almeida, 1990, p. 2).

Rômulo não a escreve sozinho. Conta com o apoio de uma legião de servidores públicos, cerca de 50 pessoas. A equipe básica fora composta por ele, Jesus Soares Pereira, Ignácio Rangel e Saldanha da Gama, este último, técnico de administração do DASP.

Tal empreitada por ele descrita como "aventura" teria de partir praticamente do nada. A administração passada não havia "deixado uma folha de papel escrita sobre os dados do exercício de 1950” (Almeida, 1990, p. 2).

"A única saída era recrutar, a toque de caixa, uma equipe de sujeitos que sabiam as coisas em cada um dos setores", o que não lhe fora difícil, pois "possuía a vantagem de ter certo conhecimento dos quadros públicos e um bom relacionamento com o pessoal". Tinha a capacidade de arregimentar e colocar o pessoal técnico para trabalhar em equipe não de maneira impositiva, mas motivado por um senso de missão. Deve-se somar a existência de um novo tipo de funcionário público, plantado pelo sistema de mérito do DASP e comprometido com os destinos da nação (Almeida, 1990, p. 2; Oliveira, 2012; Pedrão, 2012).

Muito do pessoal recrutado já fizera parte da comissão encarregada de preparar os estudos para a criação do Instituto de Serviços Sociais do Brasil (ISSB), sob a liderança de João Carlos Vital - iniciativa de 1945, abortada pelo presidente Dutra, ou da assessoria da Comissão de Investigação Econômica e Social da Assembléia Nacional Constituinte, de 1946, sob a liderança de Horacio Lafer. No dizer de Rômulo, esse grupo tinha registrado um retrato da vida social brasileira. Então, voltava a reunir-se em um novo contexto político (Almeida, 1990, p. 3).

A leitura da mensagem revela a dificuldade da empreitada. Não podia ser apenas um documento técnico, tinha de incorporar o nacionalismo getulista, agora em moldes democráticos, "mas deixando a coisa um pouco fluida para evitar que as palavras comprometessem o governo". Ainda assim, entraria para a história do pensamento econômico como "o mais amplo documento de afirmação da industrialização integral até então escrito no Brasil”. (Almeida, 1985a, p. 48; Bielschowsky, 1995, p. 339).

O documento, depois da introdução de cunho político, aborda a questão internacional, o quadro administrativo e a situação econômico-financeira, quando introduz o problema da produção. Neste capítulo, além dos vários segmentos da produção, tem destaque a dupla sagrada "transporte e energia", os planos regionais e o papel dos capitais estrangeiros. A mensagem termina com um amplo capítulo sobre o "progresso social" em suas diversas vertentes.

Elaborada a mensagem, Rômulo é confirmado na Chefia da Assessoria Econômica. As funções desse órgão eram variadas, mas podem ser divididas em 
dois tipos principais. Por um lado, havia a administração econômica de curto prazo, feita por meio de despachos cotidianos com o Presidente. Por outro lado, a atividade, mais estratégica e de longo prazo, visava a avançar um planejamento para atacar os principais gargalos da produção. Tal planejamento, ainda que não declarado, caracterizava-se pela orientação nacionalista e preocupação com a eficiência econômica e social.

Tinha Rômulo e sua equipe liberdade propositiva. Atuavam dando concretude aos projetos presidenciais e dos ministros, muitos dos quais chegavam às mãos da Assessoria de maneira bem "imatura". Em algumas iniciativas, assumiam a negociação política, sempre por delegação do presidente Vargas, mas jamais participavam dos louros. Depois da contenda, retiravam-se de volta aos bastidores. (Almeida, 1990, p. 5-7, 11)

O depoimento de Rômulo é esclarecedor da forma de inserção da Assessoria na máquina pública.

Inclusive nós fazíamos coisas e entregávamos aos ministros. Primeiro vendíamos a idéia [sic] ao ministro, e o ministro ficava satisfeito, porque a gente dava uma boa idéia [sic]que ele ia brilhar, ele ia faturar, entendeu? Apresentava a exposição de motivos ao presidente, apresentava o decreto dele e tal e pronto. Então quem era mais importante? Era uma questão de examinar, e só um historiador pode dizer (Almeida, 1990, p. 11.)

Com certeza, eles atuavam no cerne do aparelho de Estado, imprimindo seus valores, integrando atividades que corriam o risco de fragmentar-se e buscando deslocar interesses de natureza essencialmente clientelista. Instauraram uma espécie de "conspiração assessorial", blindando, ao menos parcialmente, a máquina pública contra as demandas centrífugas e imediatistas de grupos sociais e regionais (Almeida, 1985a, p. 36-37).

Como definir o novo ator social, atuando dentro das malhas do Estado e motivado pela busca do que chamavam de "interesse nacional"?

Em primeiro lugar, não eram meros técnicos. Rômulo mesmo retifica quando lhe lançam essa alcunha na entrevista de 1980 para o Centro de Pesquisa e Documentação de História Contemporânea do Brasil (CPDOC/FGV), transcrita e publicada dez anos depois. Diz o servidor público-economista "Eu era um técnico pela necessidade de informação e também de ganhar dinheiro, porque eu sempre tive preocupação política, mas também não tinha fana eleitoral" (Furtado, 1998a, p. 152).

A melhor definição sobre o tipo social encarnado por Rômulo e outros servidores públicos de sua geração seria a coletada por Lourdes Sola com outro herói do desenvolvimentismo brasileiro, Celso Furtado, seis anos mais jovem que o economista baiano. Observando seu depoimento: 
Não diga tecnocratas (...) sim, técnicos é correto. Tecnocratas não existiam naquele tempo (...). Foi só nos anos 50 (e não no primeiro governo Vargas) que se formaram técnicos em fins (...). O fato de que o homem tem objetivos não pode ser dissociado de sua capacidade de usar a razão (...). É por isso que a distinção introduzida por Weber entre racionalidade dos meios e a racionalidades dos fins é tão importante (Furtado, 1998a, p. 152).

\section{E Furtado não pára por aí:}

O mais interessante é que esta gente no Brasil tinha uma ligação com o Estado que era considerada essencial: se você fosse contra o Estado, você seria contra o povo, já que não havia partidos com suficiente capacidade para defender o povo, então teria que ser o Estado (Furtado, 1998a, p. 153-154).

Havia, pois, um debate em torno dos fins e das alternativas para o desenvolvimento econômico do país. Os meios dependiam de uma interpretação dos fins, os quais possuíam um quê de utopia, oportunidades a serem construídas. Suas posições políticas eram suprapartidárias e as ideias, movidas por valores. Eram, antes de tudo, "produtores qualificados de ideologias"2. A política era o objetivo, a economia um dos instrumentos disponíveis sobre o qual o conhecimento ainda engatinhava. Daí, o autodidatismo de boa parte desses economistas não por formação, mas quase por destino.

Em contrapartida, colocavam-se como intérpretes dos anseios populares, não de maneira tecnocrática, do tipo "nós sabemos o que povo quer" nem por meio de vantagens imediatistas concedidas com objetivo eleitoral. Nacional era então uma alavanca para o popular. Bem diferente do período pós-64, onde Rômulos, Furtados e Soares seriam exilados direta ou indiretamente, para darem lugar, agora sim, ao tecnocrata, ao economista-rei especialista em meios (Sola, 1998, p. 45).

Ao contrário deles, o tecnocrata emerge da suposta dicotomia entre "técnicos" e "políticos", pois que dotado de um conhecimento que se quer especializado e neutro. Sua missão é propagar aos mortais as leis inelutáveis da ciência econômica. Professam a ideologia da não ideologia, atuando como agentes da desmobilização da sociedade. (Gomes, 1994, p. 2, 6, 9; Coutinho, 2011, p. 31).

Nem todos os "técnicos em fins" eram nacionalistas. Isso porque os conflitos de classe e entre os grupos de poder eram transformados, ao menos parcialmente, em conflitos intraburocráticos.

Por mais que se soubessem partícipes de arcos distintos de alianças políticas, os citados técnicos - nacionalistas e cosmopolitas ${ }^{3}$ - conheciam-se, frequentavamse e respeitavam-se. Havia uma concepção de que a burocracia estava formando-se,

(2) O termo é emprestado de Sola (1998, p. 151).

(3) Ver definição de Sola (1998, p. 133-143). 
ocupando papel estratégico na condução da "ossatura material" do país ${ }^{4}$, articulada em torno de estruturas econômicas centralizadas pelo poder estatal. Possuíam um linguajar mais ou menos uniforme e comungavam das mesmas leituras.

A diferença estava na incorporação da nação no vocabulário econômico. Os nacionalistas viam o Brasil como uma formação histórica típica, cujo desenvolvimento não seguiria as mesmas linhas da teoria convencional. Os cosmopolitas viam o mercado - interno ou externo - como orquestrador da vida econômica. Estes, por mais que admitissem o papel supletivo do Estado, aceitavam como dada a dotação de fatores produtivos.

Bielschowsky(1995,p.33-35,240-241)prefereutilizaro desenvolvimentismo como denominador comum a estruturar o debate ideológico da época. Diferencia os desenvolvimentistas por espaço de atuação. Havia os do setor público e os do setor privado. A primeira corrente de pensamento é subdividida, por sua vez, entre os nacionalistas e os não nacionalistas.

Rômulo e seus colegas da Assessoria Econômica compunham o grupo dos técnicos nacionalistas ou dos desenvolvimentistas do setor público nacionalista, conforme a definição utilizada.

O período 1945-1955 - quando Rômulo ascende na hierarquia do setor público e protagoniza as principais ações desenvolvimentistas - pode ser classificado como o de "amadurecimento do desenvolvimentismo"s que, no decênio seguinte, viveria seu auge e crise, encontrando já em Celso Furtado a figura aglutinadora dos esforços dos nacionalistas.

Tudo indica que algo mais importante, para além da ideologia econômica e defesa do papel do Estado em suas diversas nuances, diferenciava os dois grupos técnicos desenvolvimentistas do setor público. O acompanhamento da trajetória de Rômulo permite aprofundar tal diferenciação.

Ainda que todos fossem manheinianos de alguma maneira, como admite Furtado (1998b, p. 9), a influência do pensador alemão pela literatura especializada parece exagerada ou, ao menos, distorcida. O papel do intelectual como catalizador das forças sociais, como intérprete da vontade coletiva nacional, não deve ser visto de forma ingênua, como se ele, alheio à luta de classes, planasse por sobre a sociedade, eximindo-se de participar de seu jogo intrincado.

Os técnicos desenvolvimentistas do setor público nacionalista possuíam um traço singular, pouco enfatizado pela literatura. Eram, antes de tudo, "intelectuais orgânicos do Estado" promotores do desenvolvimento. Isso não significa que vissem

(4) Este conceito é de Draibe (1985, p. 83-84).

(5) Uma periodização do ciclo desenvolvimentista pode ser encontrada em Bielschowsky (1995, p. 247248). 
o Estado como a tábua de superação do atraso ou que subestimassem os conflitos de classe nele condensados. Ao contrário, eles os presenciavam de camarote.

Viam-se, entretanto, como organizadores dos interesses sociais conducentes ao desenvolvimento nacional, assumindo-se como servidores da nação porque lograram assumir posições privilegiadas na máquina burocrática e uma direção política unificadora para a sua administração.

Se eles não colidiam com a dominação de classe encarnada pelo Estado do qual eram funcionários, como defende Coutinho (2011, p. 27) por sua vez, viam o desenvolvimento econômico como uma forma de reorganização das estruturas de classe e de poder. Por trás do imperativo nacional, havia uma ética pública, cuja origem pode ser encontrada em uma espécie de positivismo renovado pela matriz modernista e redefinido a partir da assimilação dos cânones das ciências sociais.

O texto de Helio Jaguaribe - com o qual Rômulo participara do "Grupo de Itatiaia", depois do IBESP e, de forma distante, no ISEB, quando já estava na Bahia - sumariza de maneira elucidativa a visão do nacionalismo elaborada por este grupo:

Somente, portanto, uma ideologia global do nacionalismo, tendo por fim o desenvolvimento econômico-social, pode enquadrar, em função de tal fim, os interesses situacionais de todas as classes e conduzir à liderança, no âmbito de cada uma delas, de seus setores dinâmicos e produtivos. Tal ideologia resulta na composição dos interesses em jogo, para o fim em vista, no nível das exigências culturais de nosso tempo ${ }^{6}$ (Jaguaribe, 1958, p. 65.)

Buscavam agir sobre a sociedade, plantando as sementes de uma democracia efetiva, que sabiam não emergir espontaneamente. O Estado deveria assumir o papel de formulador do desenvolvimento econômico. Não poderiam, no entanto, parar por aí, por isso se organizavam em suas próprias entidades, como o IBESP e o Clube dos Economistas, buscando pontes com outros segmentos do setor público e da vida social.

Esses servidores públicos de índole nacionalista socializavam-se no âmbito do Estado que viam não apenas como meio irrecusável para os países subdesenvolvidos - a primeira posição de Roberto Campos no início dos anos 507 -, mas como ponte privilegiada para que vicejasse uma "sociedade civil" capaz de redefinir os rumos da "sociedade política" eivada de clientelismo.

Utilizando-se da abordagem gramsciana, é quase como se tal posição de classe - reproduzida no âmbito do aparato estatal - lograsse incentivar a formação de "aparelhos privados de hegemonia" de modo a fugir das artimanhas conciliatórias provenientes dos setores mais retrógrados, encastelados na estrutura de poder e,

(6) Ver Jaguaribe (1958, p. 65).

(7) Ver os primeiros textos da coletânea Campos (1963). 
inclusive, manietavam a própria realização do projeto desenvolvimentista. Eles se viam, portanto, como artífices e beneficiários potenciais das lutas internas que travavam no sentido da crescente socialização da política, apenas possível por meio de uma efetiva "democratização da vida social brasileira".

Tal posição de classe, talvez diminuta em termos numéricos, cumpriu um papel estratégico em termos de ação econômica e política. Já foi visto como Rômulo referia-se à "conspiração assessorial" de que faziam parte. A derrota paulatina que sofreriam frente aos técnicos desenvolvimentistas do setor público não nacionalista os quais atuavam de modo crescente como intelectuais orgânicos de grupos privados, estrategicamente alojados no setor público - repercutiria na própria capacidade de coordenação estatal e de transformação das estruturas econômicas e sociais.

Não convém aqui questionar as interpretações sobre o Brasil pós-1930 como um caso típico de "modernização conservadora", de "via prussiana" ou de "revolução passiva". Tais enfoques possuem um potencial analítico ainda não esgotado, especialmente quando se avalia o papel desses "intelectuais orgânicos do Estado" como componente social, político e cultural a iluminar a reflexão sobre a realidade brasileira.

Segundo Vianna (2004, p. 43-46), por exemplo, o Brasil figura na América Ibérica como "o lugar por excelência da revolução passiva", caracterizada pelo "conservar-mudando", a partir de conciliações pelo alto, organizadas no âmbito do Estado. Trata-se, assim, de travar as possibilidades revolucionárias das mudanças políticas, econômicas e sociais, geradas a partir de um novo andamento da vida interna frente aos cenários internacionais cambiantes.

Para o mesmo autor, entretanto, a Revolução de 1930 não deixa de provocar uma ruptura parcial nessa tendência. Trata-se aqui efetivamente de uma modernização conservadora no sentido tendencial de uma revolução burguesa. Ademais, ao invés da inércia das forças da sociedade, ou seja, do mero acordo de elites, que leva ao "protagonismo dos fatos", agora se abrem novas oportunidades ao "ator". Em poucas palavras, o elemento de antítese ao reformismo pelo alto tem uma brecha para enraizar-se, levando a caminhos inusitados, já que "a revolução passiva deixa de ser o cenário exclusivo das elites" (Vianna, 2004, p. 48-49).

O problema é que a esquerda - o autor tem o PCB em mente - para atuar sobre a transformação social deveria fazê-lo "num terreno estranho ao seu, o do Estado, da burguesia industrial e das elites políticas de tradição territorialista" (Vianna, 2004, p. 50).

(8) Aproveitam-se os autores das categorias gramscianas trabalhadas por Coutinho, 2011, para fornecerem uma leitura alternativa das relações entre burocracia estatal e forças sociais e políticas durante os anos 1950. 
Que dizer, no entanto, da "esquerda" em diálogo com os representantes dos movimentos sociais, profunda conhecedora do Estado, próxima à burguesia industrial e convivendo diariamente com as elites agrárias - na maioria das vezes inclusive de maneira conflitiva com seus apaniguados nos governos federal e estadual?

Essa espécie de contraelite composta pelos intelectuais orgânicos do Estado, não se quer ver como demiúrgica. Ao contrário, estava enraizada socialmente a partir de um locus de atuação privilegiado. O problema é que tal lugar vai enfraquecendose já no governo JK, ao passo que a "esquerda comunista" caracteriza-se pela ausência de coerência propositiva e reduzida representatividade, preferindo manterse distante do Estado elitista e acreditando na ficção de uma "revolução democráticoburguesa"9.

Pode-se agora, sob um novo prisma, aprofundar a análise do segundo Governo Vargas e do confronto/diálogo entre os técnicos nacionalistas e cosmopolitas, que ocupavam arenas burocráticas distintas, mas superpostas: o primeiro grupo, em torno da Assessoria Econômica, enquanto o segundo atuava no âmbito da Comissão Mista Brasil/Estados Unidos (CMBEU).

Para além das visões que partem de um maquiavelismo inerente à figura de Vargas, este optara por acalmar as desconfianças norte-americanas, nomeando Horácio Lafer para a Fazenda e João Neves de Fontoura para o Itamaraty. Eles dariam sustentação à Comissão Mista Brasil-Estados Unidos (CMBEU) que agrupava, em grande medida, os economistas do setor público não nacionalista, procurando avançar projetos a contarem com o financiamento norte-americano, via Eximbank ou Banco Mundial.

Paralelamente, Vargas precisava de uma assessoria direta, de sua inteira confiança, para avançar soluções de longo prazo na área de infraestrutura econômica e social, que partissem de uma concepção própria de desenvolvimento e contassem com participação destacada, ainda que não exclusiva, do Estado.

No depoimento de Rômulo, "havia entre os dois segmentos da administração econômica certo entendimento, não havia conflito". A Comissão atuava mais como escritório de projetos, enquanto a Assessoria concentrava-se no problema energético (Almeida, 2004, p. 131-132).

A equipe da Assessoria participaria de subcomitês da CMBEU, tendo apoiado muito a criação do BNDES, que inicialmente funcionou como solução de consenso entre os dois grupos (Almeida, 1985a, p. 42-43).

O próprio Rômulo admite, contudo, que "a Assessoria obedecia a uma política, e a Comissão a outra”. Apesar das relações amistosas, ele afirma: "o pessoal da Comissão Mista era um pessoal essencialmente anti-estatista [sic], privatista,

(9) Ver diagnóstico de Prado Jr. (1966). 
a favor da Light, a favor das Empresas Elétricas Brasileiras", "enquanto a nossa política era fazer um Estado atuante" (Almeida, 1990, p. 8).

As divergências, por vezes, eram deixadas de lado, em prol de uma administração eficiente que não fosse engessada por embates ideológicos. Rômulo muitas vezes conferira apoio a Lucas Lopes e Roberto Campos, mesmo discordando de algumas de suas “idéias liberais". Ao mesmo tempo, muitos técnicos da Assessoria, como Heitor Lima Rocha, Ewaldo Correia Lima e Ignácio Rangel ocupariam posições de relevo no BNDES, depois que este órgão entrasse em operação (Almeida, 2007, p. 203).

Roberto Campos, que prefere autoqualificar-se como "desenvolvimentista liberal", também destaca a divergência de visões entre os dois grupos, ressaltando como o BNDES não deveria participar da montagem dos monopólios estatais no setor de energia, porque "favorecíamos o estímulo do desenvolvimento destas atividades, através da iniciativa privada" (Campos, 1994, p. 197, 203, 331).

No entender de Campos, o BNDES deveria contribuir para transformar pontos de estrangulamento em pontos de germinação, por meio do planejamento seccional, entrando o Estado apenas onde o capital de risco não estivesse disponível. Já, Rômulo e sua equipe advogam uma estratégia de planejamento integral, comandado pelo Estado, a qual seria mais tarde esmiuçada por Furtado no Grupo Misto Cepal/ BNDE entre 1954-1955 (Bielschowsky, 1995, p. 111-113, 132-133, 147).

A despeito das nuances que separavam os dois grupos, durante o segundo Governo Vargas, teria ocorrido "uma fertilização recíproca entre os dois grupos de técnicos", dissolvendo de maneira gradual, mas não definitiva, as diferenças de origem doutrinária. Aglutinavam-se em torno de uma ideia força-unitária: o desenvolvimento acelerado como prioridade essencial ${ }^{10}$, o que, aliás, diferenciava os técnicos cosmopolitas da abordagem mais rígida de Eugênio Gudin. O abismo ético - passível de ser resumido na disjuntiva nação ou mercado - parecia, ao menos até o momento, congelado.

Essa coexistência entre os dois grupos de técnicos desenvolvimentistas seria reforçada durante o governo de $\mathrm{JK}$, ao mesmo tempo em que se criavam as condições via internacionalização do mercado interno e estreitamento das opções políticas, já no período posterior pré-golpe, para seu distanciamento irreconciliável.

Como resultado, houve muito de continuidade, mas também de descontinuidade entre o governo Vargas e o de JK. É como se o projeto "varguista" de Rômulo tivesse sido transformado à revelia de tal maneira que ele já não se reconhecia no Brasil de "50 anos em 5". Obviamente, trata-se de uma visão que o economista baiano apenas desenvolveria mais tarde, apoiado no sentido assumido pela história.

(10) Ver Sola (1998, p. 110-111). 
Por um lado, vê-se que o Brasil de JK não existe sem a Petrobras, o Fundo Federal de Eletrificação, o Plano Nacional do Carvão, a Capes, o BNB e seu Etene - que desembocariam na Sudene - e a SPVEA, iniciativas comandadas por Rômulo. Este, sem o Conselho de Desenvolvimento Industrial e a Subcomissão de Jipes, Tratores, Caminhões e Automóveis que se transformariam, respectivamente, em Conselho de Desenvolvimento, agora, com a máquina do BNDES por trás e no Grupo Executivo da Indústria Automotiva (GEIA) (Latini, 2007, p. 97-107).

Por outro lado, um conjunto de iniciativas abortadas como a Comissão Nacional de Política Agrária e a Comissão Nacional do Bem-Estar Social, além de inúmeras iniciativas setoriais como na área de biomassa, de infraestrutura e nos transportes com o engavetamento do projeto ferroviário, sem deixar de mencionar a Comissão Nacional de Energia Nuclear, também, protagonizadas por Rômulo e sua Assessoria Econômica (Almeida, 2004, p. 138-139).

Este conjunto de iniciativas em várias frentes - infraestrutura, regional, social, todas moldadas por uma concepção sistêmica de planejamento - é o que faz com que Hélio Jaguaribe (1995, p.77) considere Rômulo “o principal arquiteto do desenvolvimento brasileiro nos anos 50". Seu papel fora o de coordenar uma equipe técnica bem preparada e posicionada na máquina estatal. O período em que ascende na máquina pública coincide com a afirmação do "intelectual orgânico do Estado", que ele encarna. Daí, a menção honrosa de Jaguaribe, talvez mais a realçar a posição que ele ocupava, do que suas qualidades técnicas ou pessoais.

Por mais que se questione a forma como Rômulo e outros de sua geração idealizaram a figura de Vargas, o importante é que essa idealização origina-se a partir de iniciativas concretas e de uma forma de gestão da máquina pública, na qual os técnicos nacionalistas possuíam papel, senão preponderante, ao menos de destaque.

Em síntese, caso se observe o Brasil a partir do prisma de Rômulo, talvez se perceba que o Estado Novo fora um mal menor quando tomado em perspectiva histórica. Deturpara a Revolução de 1930, mas dera novo fôlego às instituições estatais, para que elas pudessem completar a obra inacabada, agora em um quadro de democracia com apoio popular às políticas nacionalistas de expansão da infraestrutura econômica e social.

Era como se Rômulo reinventasse o próprio Getúlio, único líder capaz de concretizar a utopia nacionalista. Por sua vez, Getúlio via em sua assessoria econômica a manifestação de seu positivismo, necessitado de modernização em um ambiente democrático.

Essa reinterpretação do legado varguista por Rômulo e outros técnicos nacionalistas seria confirmada a partir da convivência diária com o presidente na Assessoria Econômica, quando atestaram tamanha capacidade de aprovar os 
projetos por eles elaborados. Não negavam o clientelismo de Vargas, mas saudavam sua capacidade "de distinguir as áreas em que ele podia permitir o clientelismo", daquelas consideradas estratégicas (Almeida, 1985a, p. 37).

No entender deles, não havia alternativa, ou as existentes eram muito piores: giravam em torno do "democratismo udenista"11 ou das palavras de ordem do PCB, cuja cúpula se mostrava distanciada da estrutura do poder político e incapaz de apreender as reais contradições vividas pelo país em intensa transformação.

Deixa-se, então, mais uma vez a palavra com Rômulo. Sobre o Estado Novo, ele diria:

O processo de afirmação de uma política nacional não caminhava muito pela linha do processo democrático. Caminhava, eu suponho, mais neste diálogo entre os tecnocratas e a burguesia industrial, de um lado, e de outro, nas grandes forças ligadas ao sistema de comunicações e a todos os interesses tradicionais que estavam associados sempre à idéia do capital estrangeiro como salvador da pátria (Almeida, 2007, p. 196).

Ainda:

Um Estado que fosse capaz de fazer coisas, de associar-se à burguesia industrial e mobilizar também as massas, para que esta representação dos trabalhadores representasse, por um lado, o apoio que faltava pela via eleitoral e, por outro, o contrapeso da tendência concentradora da burguesia industrial. (Almeida, 2007, p. 196).

De qualquer modo, as pontes entre 1930, 1937 e 1951 são complexas. Há muito de ruptura e continuidade, variando a interpretação conforme o posto de observação, o que aguça ainda mais a complexidade do quadro político. Nem 1937 seria mera decorrência de 1930 como cogitaram os intelectuais estadonovistas ${ }^{12}$. Tampouco, 1951 um complemento de 1930, com o reforço das instituições estatais no meio do caminho ${ }^{13}$, como talvez tenham acreditado Rômulo e outros técnicos, quase como justificativa para prosseguir no campo de batalha, em defesa da ampliação das possibilidades democráticas, por mais que soubessem das excessivas concessões a serem feitas aos grupos oligárquicos agora reciclados econômica e politicamente.

Fato é que a oligarquia sairia deslocada, se não como classe dominante, ao menos enquanto classe dirigente, conforme Penna (1999, p.150-151). O Estado Novo criara uma espécie de atalho/desvio para que se encontrassem novas formas

(11) A expressão é de Pereira (1988, p. 30).

(12) Os teóricos do pensamento autoritário veriam essa continuidade como movimento no sentido inverso ao "de lenta decomposição do país", já que assim definiam a Primeira República e seu liberalismo (Gomes, 2005, p. 191-193).

(13) Apenas a partir de 1942, o Estado Novo passa a experimentar uma crescente "ambiguidade política". Isso se dava na medida em que se procurava "conduzir o processo de saída do autoritarismo", com base em uma política não apenas de controle do movimento sindical, mas também de "adesão e mobilização" (Gomes, 2005, p. 182-188). 
de incorporação ao Estado das camadas sociais heterogêneas, redefinindo inclusive a forma de operação dos interesses regionais particularistas. Fora, então, a saída encontrada para lidar com desafios que emergiam coligados e não na sequência como nos países avançados: a integração nacional, a participação política e a redistribuição de riqueza ${ }^{14}$, ou seja, o nacionalismo varguista seria, no máximo, virtualmente democratizante.

Essa "revolução impossível", porque feita por políticos cautelosos, não seguiria um roteiro linear para Iglesias (1993, p. 231-235). A proposta de "revisão da vida nacional" ou de "republicanizar a República", lançada pelos tenentes, seria engavetada no formato original, ressurgindo sob outro figurino sem desalojar os grupos oligárquicos da estrutura de poder, mas viabilizando uma nova articulação de forças a partir do Estado para a qual contribuiriam de maneira destacada os técnicos nacionalistas.

Vale lembrar que tal estandarte fora empunhado por servidores públicos, como Rômulo, que faziam experiência técnica e apenas excepcionalmente no âmbito partidário. $\mathrm{O}$ aval, entretanto, que tinham de Getúlio não era pleno e adiante, menos ainda o teriam. Em paralelo, a própria industrialização criaria novas forças sociais poderosas, as quais delimitavam o raio de manobra do Estado e não mais em um sentido desenvolvimentista como propalado por Rômulo e companhia. Agora, o Estado - apesar de toda a pregação tecnocrática - passaria de demiurgo a coadjuvante, ainda que o processo se mostrasse muito complexo e sujeito a ziguezagues contínuos.

Como se viu, a posição privilegiada de Rômulo permite inclusive matizar algumas das análises clássicas sobre o período. Todas elas avançam na peculiaridade da conformação social e política brasileira no quadro de expansão das forças produtivas do capitalismo inter e (trans)nalizado. Elas, porém, se detêm diante das oportunidades limitadas, seja pela atitude conciliadora do Estado, seja pela fragilidade dos atores sociais - no que estão corretos como historiadores que olham pra trás tendo em mente o futuro tornado presente que conhecem - para revolucionar as estruturas econômicas e sociais a partir de um projeto nacional de desenvolvimento.

Sua principal fraqueza está em supor que o destino histórico estava traçado de antemão. Então, se o Rômulo dos anos 1950 poderia antever a debilidade do bloco de poder que lhe conferia relativa autonomia, não imaginava que ela se transmudaria no golpe de 1964 e na vitória do capitalismo excludente, returbinado pelo apoio das instituições estatais as quais ele ajudara a criar, mas agora como mera máquina de acumulação do capital.

(14) Ver Santos (2006, p. 18-21). 
Falta acrescentar ainda que, antes do golpe, Rômulo Almeida desempenharia funções estratégicas no governo da Bahia e em instituições internacionais. A dupla incursão apenas se explica se houver entendimento de que, para o economista, a nação precisava integrar-se para dentro e para fora.

Depois de renunciar ao cargo de presidente do Banco do Nordeste do Brasil, após a morte de Vargas, e de ser eleito deputado federal pela Bahia, mandato que praticamente não exerce, Rômulo torna-se, em 1955, Secretário da Fazenda de seu estado. Repete a experiência da mensagem presidencial de Getúlio. Agora, ao invés das "pastas Geka" que abrigavam o conteúdo da mensagem presidencial, Rômulo e sua equipe organizam "as pastas cor-de-rosa" em referência à cor de suas capas, contendo os subsídios para a elaboração de um planejamento à economia baiana. O diagnóstico embasaria a atuação da Comissão de Planejamento Econômico (CPE), criada formalmente em maio de 1955. Essa agência cuidaria desde questões econômicas até problemas do centro histórico de Salvador e temas urbanos em geral, inclusive na área da habitação. No dizer de Rômulo, como sempre utilizando o pronome no plural, "fizemos a primeira equipe multidisciplinar para planejamento governamental no Brasil", com engenheiros, economistas, arquitetos, gente da educação e da saúde (Almeida, 1986, p. 95-96).

A CPE contava com um Conselho de Desenvolvimento como órgão superior, do qual participavam lideranças empresariais e agências de desenvolvimento e técnicas do Estado, além de conclamar a participação da sociedade para o acompanhamento da gestão e execução de projetos. No dizer de Pedrão (2012), Rômulo que instaurara a primeira instituição de financiamento na América Latina a pautar-se pelo critério de orçamento por projetos, o Banco do Nordeste do Brasil (BNB), aplicaria o mesmo modelo na Bahia. A CPE funcionava, na verdade, como escritório de elaboração de projetos, cuja fundamentação era fornecida pelo Instituto de Economia e Finanças da Bahia (IEFB), compondo um verdadeiro sistema de planejamento (Pedrão, 2012; Almeida, 1986, p. 95).

Avançara Rômulo para a formatação de instituições públicas destinadas a ativar a economia baiana - muitas das quais funcionariam a pleno vapor nos governos seguintes -, abrindo espaço para o setor privado, sem deixar de lado os impactos sociais do processo de modernização. Em 1956, redige o documento "Participação da Bahia na Vida Nacional", enviado pelo governador baiano ao presidente JK recémempossado, no qual prenuncia a necessidade de acionar políticas de desenvolvimento regional no país (Pedrão, 1995, p. 71).

Voltaria para a CPE, na condição de Secretário sem Pasta ${ }^{15}$, em 1959, do governo Juracy Magalhães, da União Democrática Nacional (UDN), com o qual

(15) Sua nomeação seria para Secretário para Assuntos do Desenvolvimento, mas atuaria como uma espécie de Secretário do Exterior, tratando de tudo que fosse a projeção da Bahia para fora do estado, seja com o governo federal, mas também com instituições como o BID (Almeida, 1986, p. 109). 
rompe em 1961. No segundo período, mantém total apoio como representante do governo baiano junto ao Superintende da Sudene, Celso Furtado, ainda que tivessem diagnósticos diversos sobre o problema do Nordeste.

Durante a sua participação intermitente no governo da Bahia, lançaria as bases para a diversificação da economia do estado, que se completaria com as iniciativas do Centro Industrial de Aratu e do Polo Petroquímico de Camaçari, já no governo militar, mas sob a inspiração de Rômulo, o qual passara a atuar por meio de sua consultoria de projetos, a CLAN.

Assim como no âmbito nacional, sairiam de Rômulo e sua equipe as principais instituições que norteariam o desenvolvimento baiano - também aqui desviadas de seu propósito original. Geradoras de transformações, sim, mas não no sentido idealizado por seu parteiro.

Contaria com um cenário propício em seu estado natal, a começar pelas operações da Petrobras, com a construção da refinaria Landulpho Alves e pela chegada da energia de Paulo Afonso. A Universidade Federal da Bahia (UFBA) e o governo estadual planejador agiam como "geratrizes do processo social", criando uma cultura pública, cosmopolita e enraizada no meio cultural. A frase sintética de Glauber Rocha - "destruir a província na província” - encarnava o espírito da época (Risério, 2004).

O professor Chico de Oliveira (2012) afirma que "Rômulo criou a Bahia moderna". Lessa (2012) completa: "eu diria que ele foi o homem da modernização do Brasil e de todo o Nordeste em particular, o primeiro a acreditar na sua realização".

A saída definitiva do governo baiano em 1961 acontece pelo confronto com os quadros locais desse partido. Por mais que fosse filiado ao PTB, desde 1950, jamais disputara cargos na estrutura do partido, inclusive se indispusera com vários de seus membros, o próprio Jango, pela não aceitação de indicações pessoais durante os postos que ocupara no âmbito federal (Almeida, 1988).

Aos poucos, vão-se estreitando as opções para um homem público decisivamente nacionalista, mas sem qualquer apreço pelas pregações ideológicas de caráter meramente retórico ou pela mera ocupação de cargos no poder Executivo. Ainda assim, mostrava-se fiel ao partido, como o prova a participação assídua na campanha do Marechal Henrique Lott.

Rômulo receberia ainda inúmeros convites de Jânio Quadros, um dos quais, para reorganizar o sistema de planejamento de seu governo e isso, para o recémempossado presidente, era um posto equivalente ao de ministro.

Jânio governava por meio de bilhetes, muitos dos quais iam direto ao Diário Oficial. Ele nomeou Rômulo para cargos os mais diversos possíveis, muitos sem 
o conhecimento deste, como para participar do grupo de análise sobre o problema agrário, organizar o serviço de assistência aos estados dentre outros.

Assim, Rômulo descobre ter sido nomeado delegado do Brasil para a Conferência Inaugural da ALALC. Ainda mais, o ministro das Relações Exteriores Afonso Arinos já havia negociado com sua contraparte argentina para que o Brasil assumisse - ou melhor, Rômulo - a Secretaria Geral do mais novo organismo criado para fomentar o comércio entre os países da região. Vale lembrar que o "convite" não fora simples arroubo do Dr. Jânio. Rômulo, quando designado pelo presidente para uma conferência da Cepal, fizera-lhe um relatório sugerindo que o Brasil deveria apoiar a integração latino-americana (Almeida, 1986, p. 119-121).

Rômulo termina por concordar, com receio de ficar de escanteio no país, já que "havia fechado as portas na Bahia, no Rio e em Brasília também”. Aceita o desafio e embarca para Montevidéu com um passaporte diplomático na mesma semana, para tomar posse na Secretaria Executiva da ALALC em 31 de julho de 1961 (Almeida, 1986, p. 121).

Por ironia do destino, ele se sente no dever de receber o novo presidente João Goulart - inclusive arriscando seu cargo -, quando este desembarca na capital uruguaia retorna do périplo asiático, ainda como vice-presidente, ao Brasil. Depois, encontraria apoio para manter-se no cargo de nada menos que San Tiago Dantas, agora ministro (Almeida, 1988; 1986, p. 121-122).

Em 1962, todavia, ele passa a questionar o ritmo lento da integração, sentindo-se uma figura decorativa. A gota d' água foi a Conferência da ALALC na cidade do México, no final do ano. Rômulo sanciona o pedido de ingresso de Cuba à nova organização, recebendo represálias de membros do Comitê Executivo. Decide sair, mas não renuncia, pois não quer que o Brasil perca a Secretaria Executiva.

Coincidentemente, Celso Furtado, então ministro do Planejamento, está no México para uma reunião paralela, a do Comitê Interamericano Econômico e Social (CIES). Havia sido recém-criado o Comitê dos Nove Técnicos de Alto Nível da OEA, para monitorar as atividades da Aliança para o Progresso na região. Com a renúncia de Ari Torres, o Brasil ficara sem representante. Raúl Prebish faz-lhe o convite para aceitar o novo cargo, ao que ele responde que prefere voltar ao Brasil. Furtado inclusive concorda que Rômulo seria mais útil combatendo nas trincheiras nacionais. Jango acaba apoiando a nomeação Rômulo, que a interpreta como "um desejo de que ele ficasse um pouco longe" (Almeida, 1986, p. 122-124). Rômulo comenta sua decisão:

Então eu fui para a Comissão dos Nove, também forçado, tangido pelo destino, aliás nunca tive no exterior meu desejo, sempre fiz força para encargos no Brasil, mesmo fora da capital, pelo destino fui catapultado para numerosas conferências no exterior. Morava em Montevideo [sic], passei a morar em 
Washington. A única coisa que eu desejara do exterior, não consegui, foi bolsa, no tempo era difícil, queria passar uns dois anos fora estudando (Almeida, 1986, p. 124).

"Ficaria apagado" e, "felizmente", em seu entender, pois a "Revolução" pegá-lo-ia longe, tendo inclusive sido reeleito para o Comitê dos Nove em 1965. Apesar de amigo pessoal do presidente Castelo Branco, poderia ter tido o destino de Celso Furtado e Jesus Soares Pereira, ambos exilados (Almeida, 1986, p. 124).

Quando volta, depois de renunciar ao Comitê dos Nove, em 1966, em repúdio à posição norte-americana cada vez mais unilateral, faz isso na "ânsia de contribuir para a resistência democrática" de seu país, segundo Almeida (1986, p. 126). Reassume seu cargo no Ministério, com uma remuneração modesta e recusase a aceitar qualquer posto em autarquias ou comissões, embora procurasse, sempre que possível, interferir nos meandros da máquina burocrática, cujos ocupantes ainda conhecia como ninguém, apesar de agora já tomada pelos tecnocratas e eivada de pressões clientelistas de todos os tipos, fazendo os acordos getulistas parecerem coisa de criança.

É quando funda a CLAN, empresa de consultoria radicada na Bahia, que conta com um escritório no Rio, onde continua sendo acionado para dar suas opiniões e formular iniciativas e projetos de governo para a Bahia e ao governo Geisel, momento em que o país volta a curvar-se a uma diretriz retórica mais nacionalista. Segundo sua própria definição, sem esconder certo traço de orgulho: "eu era um homem público que se recusava a privatizar-se" (Almeida, 1988).

Rômulo ficaria como uma espécie de reserva moral do desenvolvimentismo brasileiro, com uma folha de serviços corridos extensa, tendo trabalhado em todos os governos desde Vargas, em postos de prestígio, sendo ademais reconhecido como figura de proa no planejamento baiano e ardoroso defensor da integração latinoamericana. Por mais que intransigentemente à esquerda, não desdenhava a política - filiando-se ao MDB em 1966 - e não se eximia de dar opiniões de conteúdo técnico onde quer que fosse chamado, mesmo durante a ditadura militar, sobretudo quando da luta pela redemocratização ao aproximar-se de Ulisses e Tancredo.

É esse Rômulo, já aos sessenta anos, hoje totalmente desconhecido, que irá refletir sobre sua trajetória ao longo dos anos 1970, produzindo explicações originais sobre os limites e potencialidades do desenvolvimento nacional, sem entregar os pontos, mesmo nos momentos mais difíceis.

\section{Os anos 1970: desilusão, combate e a dialética planejadora}

Rômulo, durante a ditadura militar e o início do processo de redemocratização, retoma vários dos temas a que se dedicara como servidor público entre os anos 
1940 e 1960. A reflexão agora avança nutrida pela práxis vivida, mas sem deixar de dedicar-se às possibilidades de ação corretiva, mesmo que reconheça as distorções do "modelo econômico" e o fechamento autoritário do espaço político.

Focar-se-ão, aqui, três questões que articulam a análise crítica de Rômulo no período pós-desenvolvimentista, sempre reiterando que ele não quer recuar no tempo, mas dar um salto adiante. São elas: i) o novo modelo econômico e político; ii) a recuperação da noção de planejamento integral; iii) e a superação das disparidades regionais.

Serão apresentados dois "textos" do início dos anos 1980. No primeiro, Rômulo diz-se "revendo a experiência empírica" e busca confrontá-la com "o repositório, hoje muito mais rico, do pensamento acadêmico sobre os problemas do subdesenvolvimento, particularmente, os de uma região periférica condicionada a uma unidade nacional" (Almeida, 1982, p. 2).

Aponta para as limitações do instrumental teórico convencional frente a um sistema econômico dinâmico, já que os elementos invariantes dos modelos "mudam e mudam inclusive qualitativamente". Termina apontando para a necessidade de resgate de uma nova economia política, inspirada pela preocupação ética e social e redefinida pelas questões postas pela realidade brasileira. É o último Celso Furtado que ele cita $^{16}$. Para além, contudo, das formulações teóricas de Furtado, que ele sempre acompanhara de perto em busca de categorias e conceitos operacionais, Rômulo continua a residir no horizonte possível de atuação, projetando utopias e buscando a superação dialética do regime militar (Almeida, 1982, p. 3, 6).

O segundo texto, composto de notas datilografadas para um seminário realizado em Teresópolis, de 1983, Almeida (1983, p. 1) põe o dedo na ferida do capitalismo tardio gestado no país: "capacidade ociosa nos setores de ponta e na infra-estrutura [sic $]_{2}$ às custas de deficiências em agricultura e bens de consumo não-duráveis [sic] e nos gastos sociais", gerando "uma estrutura urbana disforme, a pobreza crescendo à frente da urbanização". Aqui, já se sente o eco de Rangel, de Economia: Milagre e Anti-Milagre, "pensado" ao longo das últimas duas décadas, mas publicado em 1985.

O diferencial de Rômulo está em vincular as categorias explicativas de Furtado, junto à problemática de Rangel - menos cético do que Furtado quanto às possibilidades de desenvolvimento do capitalismo no Brasil, de maneira minimamente endógena, mesmo a partir dos governos militares - ampliando o foco de análise de modo a compreender a reprodução das estruturas locais, regionais e nacionais.

(16) O livro a que ele provavelmente recorre é Pequena introdução ao desenvolvimento: um enfoque interdisciplinar de Celso Furtado (1980). 
O pensador-economista mostra como a estrutura urbana (e social) precária, associada à necessidade de concentração de poder para "sustentar o processo de ampliação imoderada do excedente", acarreta a repressão e o controle dos meios de comunicação. Por sua vez, a baixa organização política, em virtude das condições de subemprego urbano, ocasiona manifestações em grande medida espasmódicas, enquanto o controle estrito das áreas não urbanizada do interior assegura a manutenção de mecanismos casuístas. Aponta, todavia, que tais efeitos políticos poderiam ser contestados de modo efetivo e duradouro pelos novos segmentos urbanos em ascensão (Almeida, 1983, p. 2-3).

Talvez, por não ter lido a obra magna de Florestan Fernandes (1974), ele detecta o seguinte círculo vicioso: "sem a consolidação de uma moderna democracia burguesa não se amadurece um sistema capitalista", conforme Almeida (1983, p. 4). Com a centralização estatal pós-1964 e a integração do mercado, mostra como sai enfraquecido o coronelismo local, cada vez mais dependente das oligarquias estaduais. A dependência econômica, entretanto, especialmente das regiões periféricas do país, impede uma transformação política e a estrutura política impede uma transformação econômica que amplie o raio de atuação do capitalismo brasileiro.

Tal reflexão, justamente quando assume o centro do palco o economista-rei faz com que Rômulo questione o papel do economista. Ele já não é mais o técnico em fins atuando em uma sociedade minimamente plástica, próximo ao centro do poder, às forças sociais e a importantes veículos da mídia, como no período pré1964. Agora, "utilizar o oligopólio da informação é uma possibilidade rendosa" (Almeida, s.d. b, p. 1).

Ao invés da fria "engenharia econômica requintada" e calcada no "hermetismo gremial", o economista deve saber lidar com as complexas realidades sociais e políticas, de modo a obter "pequenos progressos no sistema de distribuição de renda". O problema está em que as forças sociais dinâmicas como os lavradores, os trabalhadores e os empresários "costumam interpretar equivocadamente os seus interesses de grupo", de acordo com Almeida (s.d. b, p. 3). Rômulo economistapensador, exilado do setor público, está colocando-se à disposição dos citados segmentos, mas a partir de uma lógica de ampliação da eficiência econômica e social, questionando o modelo vigente. Isso porque tais grupos sociais, especialmente nas regiões menos desenvolvidas, têm menos acesso às informações, ou seja, dependem mais do novo tipo de economista, que é o antípoda do tecnocrata, para concretizar seu potencial transformador. Um economista que busque "uma perspectiva multidisciplinar, em comunicação com os setores da sociedade, especialmente os desprotegidos e dominados, no sentido de habilitá-los ao desenvolvimento, pela informação e pela luta, já que as mudanças essenciais não podem resultar de mera atitude elitista" (Almeida, s.d. b, p. 4). 
Ao associar a transformação do modelo econômico e político com a necessidade de uma transformação no papel do economista, Rômulo revela como sua reflexão encontra-se ancorada na práxis, em plena ditadura militar, fazendo dele o último militante de sua geração a ocupar o centro do palco pela defesa do desenvolvimentismo em todas as dimensões.

Rômulo, contudo, não se destaca apenas por sua resistência. Ela está vinculada a uma renovada capacidade de análise e de formulação de instrumentos de ação coletiva. Em artigo de 1978, por exemplo, para a Folha de São Paulo, o autor mostra como já estava colocada a polêmica em torno da privatização e impactos negativos para a empresa nacional, causados pela generalização da presença estrangeira no mercado interno.

Sua argumentação é tudo menos movida pelo nacionalismo ideológico. $\mathrm{O}$ problema estaria no fato de que a abstenção do Estado enfraqueceria o crescimento econômico, além de desequilibrá-lo social e espacialmente. As empresas nacionais não dispunham de recursos para certos investimentos de longa maturação, enquanto as multinacionais não estavam dispostas a correr riscos, apenas antecipando posições vantajosas em um mercado interno seguro. Completa: "só o Estado pode fazer os investimentos, com postura promocional, o que ocorre tanto para os empreendimentos de benefício social mais que direto, como por meio da criação de externalidades para as empresas privadas". Em suma, "cresceremos menos, cresceremos mais capengas e mais dependentes" (Almeida, 1978, p. 3).

Trata-se de uma análise no calor do debate, de alguém que se sabe respeitado pelo governo de plantão e procura ampliar o alcance de suas convicções, atuando agora junto aos grupos sociais emergentes, a partir de sua experiência singular.

Para além das imperfeições de mercado que a privatização com internacionalização poderia engendrar, o cerne da questão encontra-se na "imperfeição estrutural do mercado para orientar os investimentos", o que só se faz aguçar com a velocidade das mudanças tecnológicas e mercadológicas, a longa maturação dos investimentos e a escala das operações. Uma internacionalização passiva significaria a própria castração do potencial de desenvolvimento nacional (Almeida, 1978, p. 3-4).

Qual a solução? Para Rômulo, "o reforço das empresas estatais, submetidas a uma mais eficiente coordenação administrativa, e a um lídimo controle social, de modo a cumprir o múltiplo papel que lhes cabe, inclusive o de apoiar o empresariado nacional". Essa formulação dialoga com a noção de "capitalismo financeiro" de Rangel - centrado no Estado, mas abrindo espaço para concessões à iniciativa privada - ao mesmo tempo em que resiste à fúria transnacionalizadora descrita por Furtado. 
O resgate do nacionalismo, no novo contexto, irá nutrir-se da vivência isebiana. A fórmula: "radicalidade na opção, mas flexibilidade tática no manejo". O capital externo deve trazer aporte líquido, contribuir para o aumento da produtividade, melhorar o balanço de pagamentos, sem levar ao condicionamento e alienação do poder nacional. Devem-se diferenciar ainda as tecnologias produtivas básicas das tecnologias de consumo. Do contrário, a atuação de tais empresas não permite a transferência de tecnologia e transforma-se em superfetação inútil (Almeida, s.d. c, p. 3,8$)$.

Assim, completa, em diálogo com seus contendores, se as transferências fazem-se em benefício dos empresários nacionais em prejuízo de classes com menor capacidade de disputar seu quinhão, "pelo menos a injustiça fica no Brasil, e aí permanecendo fica mais fácil reparar a injusta distribuição", conforme Almeida (s.d. c, p. 10). Segue, pois, a crença na dialética planejadora como forma de fazer emergir uma sociedade mais complexa, à medida que se internalizam os centros de decisão. É nesse sentido que Rômulo saúda o esforço do II PND, por mais que ressentisse da estreiteza de seu horizonte estratégico.

Ecoando San Tiago Dantas, ele resume o dilema: "a não coincidência entre o grupo líder do processo econômico nacional e a liderança política". Talvez, ele não percebesse que ambos são os dois lados da mesma moeda, mas está disposto a atuar em ambas as frentes de maneira simultânea. Tampouco se mostra ingênuo, pois observa que "o capital privado nacional, especialmente nos setores dinâmicos, pode lutar contra a dependência e aprofundar o apoio ao processo democrático" algo que não era mera ilusão ao final dos anos 1970 - ou "se submeter aos desígnios internacionais, compensando-se na exploração dos trabalhadores e consumidores" (Almeida, s.d. d, p. 2-3).

Em discurso como paraninfo da Faculdade Católica de Ciências Econômicas da Bahia, Rômulo sintetiza as possibilidades de desenvolvimento do país. Em seu entender, trata-se de "um país fácil do Terceiro Mundo", segundo Almeida (1977, parte II). Apesar da defasagem tecnológica, ela pode ser sanada por meio de uma renovação cultural no âmbito de um processo de desenvolvimento democrático, que aproveite ademais os recursos agrícolas, o potencial florestal e os novos minérios ainda não descobertos, além da maior unificação do território por meio das tecnologias de transportes disponíveis. Novos padrões de consumo poderiam emergir a partir da absorção e geração de tecnologias.

As condições positivas são: i) as tecnologias agrícolas desenvolvidas para o trópico; ii) o núcleo industrial nos setores de bens de capital e intermediários tanto em termos de capacidade produtiva como de manejo de uma tecnologia avançada; iii) a capacidade empresarial e dos recursos humanos ao menos nos segmentos modernos; iv) a qualidade do Estado brasileiro no que tange ao padrão de organização e de 
métodos de gestão; v) o sistema federativo, com entidades espaciais descentralizadas com relativa autonomia; vi) além da escala do mercado interno, acrescida da crescente capacidade para exportar.

Quanto às condições negativas: i) o ufanismo autoritário que engessa mudanças culturais e institucionais; ii) a semialfabetização, por um lado, e o cartorialismo gremial, por outro ladp, que concede privilégios por meio de diplomas; iii) o exagero expropriativo de uma minoria; iv) o explosivo problema urbano, que não se resolve sem mudanças no plano da distribuição e no uso da propriedade; v) o crescimento econômico gerador de dependência externa; vi) a deterioração da solidariedade e da participação que pode fazer esgarçar a cordialidade como característica nacional; vii) a postura de superioridade com relação aos demais países da região (Almeida, 1977, parte III, IV).

Após esta síntese por pares de oposição das possibilidades de desenvolvimento do país - a qual se caracteriza pela simplicidade analítica e amplo alcance dos temas abordados - Rômulo aponta para o impasse da "civilização brasileira". Sim, é esse o termo utilizado.

$\mathrm{O}$ adiamento de uma melhora distributiva junto a uma mudança na estrutura produtiva que a possibilitasse é justamente o que impede maior capacidade de geração de empregos na agricultura, áreas urbanas e, por sua vez, a elevação da capacidade de arrecadação do Estado. Melhores salários representam maior demanda para bens agrícolas e industriais, habitações e obras públicas, todas as atividades menos poupadoras de mão de obra(Almeida, 1977, parte V).

Rômulo ataca de frente a questão urbana, resultado da combinação entre pobreza e especulação imobiliária, o que o distingue dos demais pensadores desenvolvimentistas, com a exceção talvez de Rangel. Torna-se fundamental a seu projeto de desenvolvimento o controle do uso do espaço urbano, o que se concretizaria com a reforma urbana, amplamente debatida em 1963. Diagnostica, contudo, que no Brasil, "exacerba-se um privatismo, com um selvagem pré-capitalismo que tem a seu serviço a inibição anti-comunista [sic]” (Almeida, 1977, parte V).

Ora, sua passagem pela Comissão de Aplicação das Reservas da Previdência Social - burocracia atuarial unificada criada no final do Estado Novo, para administrar as reservas dos institutos de previdência - fornecera-lhe o conhecimento da dinâmica imobiliária. Os recursos disponíveis da previdência foram em grande parte investidos em transações imobiliárias principalmente na cidade do Rio de Janeiro, aproveitando-se da carência de moradias para ampliar o capital empregado e garantir a rentabilidade futura dos fundos. Rômulo foi um dos que se levantou contra essa forma de investimento, alertando para as consequências na dinâmica urbana: o agravamento das dificuldades de moradia às classes de menor renda em 
função do aumento da demanda por materiais e terrenos disponíveis (Bonduki, 1998, p.113, 119).

Finalmente, Rômulo enfrenta o Furtado de $O$ Mito do Desenvolvimento Econômico $^{17}$, ao afirmar que não está provado que o crescimento elevado do PIB exija necessariamente uma distribuição tão desigual. Significa que a desigualdade está na base da acumulação capitalista no Brasil (o que é diferente de condição), em relação à qual o Estado tem perdido a capacidade de acionar mecanismos corretivos. O modelo pode ser superado pelas próprias forças que ele engendra e pela reorganização da sociedade, acionando o Estado de maneira democrática, mas sem retirar-lhe a autonomia e capacidade propositiva. É o último canto da sereia de um capitalismo autônomo, democrático, regulado e adaptado à realidade cultural dos trópicos (Almeida, 1977, parte V).

Essa espécie de utopia pragmática associa um Rômulo cético na análise do real a outro que antevê possibilidades não antecipadas de desenvolvimento pelos modelos convencionais. A análise acontece pela filtragem do ferramental econômico por meio de uma sensibilidade aguçada pela diversidade territorial do país e pela crença na dialética planejadora.

Como culminação da reflexão, pode-se encontrar sua síntese do processo de planejamento como instrumento democrático e agente dinâmico da organização produtiva nacional, a qual seria apresentada em três aulas ministradas no Instituto de Arquitetos do Brasil, em setembro de $1975^{18}$.

Para Rômulo, a ação planejadora é um método que visa a dar racionalidade ao processo de implementação de decisões políticas por meio da interferência na dinâmica de uma determinada realidade. O grau de abrangência de tal interferência determina as diferentes escalas do planejamento, desde o planejamento geral até os programas específicos. O planejamento geral é mais político do que técnico e estabelece as diretrizes do desenvolvimento econômico e social, enquanto os programas específicos são aqueles mais técnicos os quais agem localmente.

Nas diferentes escalas e tipos de planejamento, os quadros técnicos ocupam vários papeis, como responsáveis pelos conhecimentos específicos mobilizados nos vários programas setoriais, ou ainda pelo gerenciamento do sistema de informações integrado à ação planejadora. O que Rômulo de fato ressalta, no entanto, é a importância dos técnicos como agentes mobilizadores da sociedade.

Agora, o papel do técnico ressaltado por Rômulo parece emergir diretamente

(17) Furtado (1974).

(18) Acervo do Instituto de Altos Estudos Rômulo Almeida. 
da necessidade de organização social no Brasil da ditadura militar. Um agente capaz de instituir um movimento no contrafluxo à tendência concentradora e ao modelo "autocrático" de ordenação social e urbana. Funcionaria principalmente como um agente de organização política capaz de defender a forma "nacional e desenvolvimentista" forjada em sua geração.

Em relação ao fluxo do planejamento, Rômulo apresenta um sistema que se divide em duas fases. A primeira, localizada na esfera da decisão política e avaliação preliminar das condições de sua realização. Nessa fase, definem-se os programas, as políticas e os agentes de execução. A segunda fase refere-se à execução e compreende a mobilização dos agentes, a implementação dos programas e políticas e a avaliação dos resultados obtidos. Trata-se da última etapa que irá permitir, por sua vez, a revisão das diretrizes definidas inicialmente na esfera política e também o aperfeiçoamento de todo o processo implantado.

Figura 1

Quadro-síntese da dinâmica da atividade planejadora elaborado pelos autores a partir da exposição de Rômulo

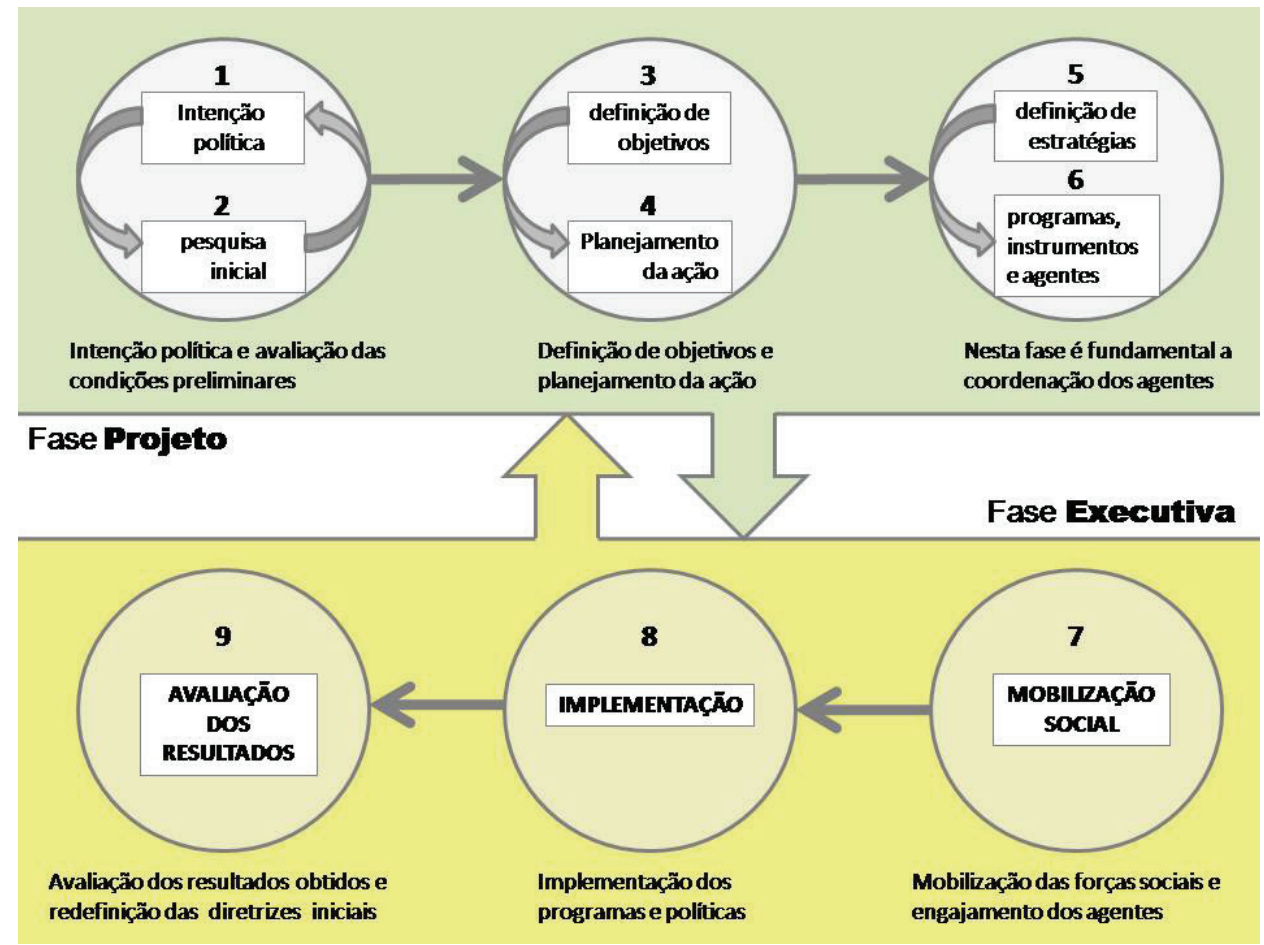

O desafio colocado pela reflexão de Rômulo é o de controlar o processo por meio do qual o plano, isto é, a intenção (utopia nacional) atua na realidade. Interpretar 
as inter-relações existentes entre as diversas variáveis que conformam a situação existente e definir quais as ações estratégicas necessárias para alcançar os objetivos planejados. Tais ações deveriam ser contempladas por programas específicos e conformariam as condições necessárias para alcançar uma nova realidade.

Em relação à tipologia do planejamento, Rômulo define que o planejamento pode variar em função da abrangência. Os planos podem ser mais gerais, como os planos nacionais, ou mais específicos como os planos regionais, municipais ou urbanos. Em suas palavras:

Uma espécie de tipologia de planejamento em termos de espaço, de extensão, o plano pode ser geral, geralmente se aplica a todo o país, a toda a economia nacional; pode ser só econômico ou social, ou pode ser plano apenas de inversões básicas ou pode ser apenas um plano de setor público, inclusive de estímulo de transferência ao setor privado; pode ser setorial, por atividade econômica; pode ser plano regional e afinal o plano urbano (Almeida, 1975a, p. 2).

Também, classifica o planejamento em função do tempo. Planos de longa duração ou prospectivos, aqueles que mais se distanciam da realidade pela limitada capacidade de previsão das variáveis as quais atuam em longo prazo. Os planos de curto prazo são mais previsíveis, mas possuem uma capacidade de transformação limitada. Os planos de médio prazo, como os de governo, os plurianuais são aqueles que mais se traduzem em mudanças concretas, segundo a explicação de Rômulo (Almeida, 1975a, p. 4).

Enfatiza que a eficiência dos planos depende de sua articulação com um sistema de informações, isto é, de um instrumento de coleta de dados adequado ao que se pretende conhecer para interferir e da interpretação correta de tais dados traduzidos em informações para o planejamento. Rômulo utiliza exemplos concretos para esclarecer os modelos explicativos que apresenta. Nesse caso, para exemplificar a relação entre planos gerais (nacionais), regionais e os programas setoriais, cita a instalação da usina hidrelétrica de Paulo Afonso.

É curioso observar que na primeira tentativa de desenvolver atividades de desenvolvimento em regiões periféricas são projetos que geralmente se incluem nos programas setoriais respectivos, como Paulo Afonso no Nordeste, mas antes do planejamento do Nordeste se incluiu no planejamento da eletricidade, no plano nacional de eletrificação (Almeida, 1975a, p. 6). 
Figura 2

Quadro-síntese da tipologia do planejamenento elaborado pelos autores a partir da exposição de Rômulo
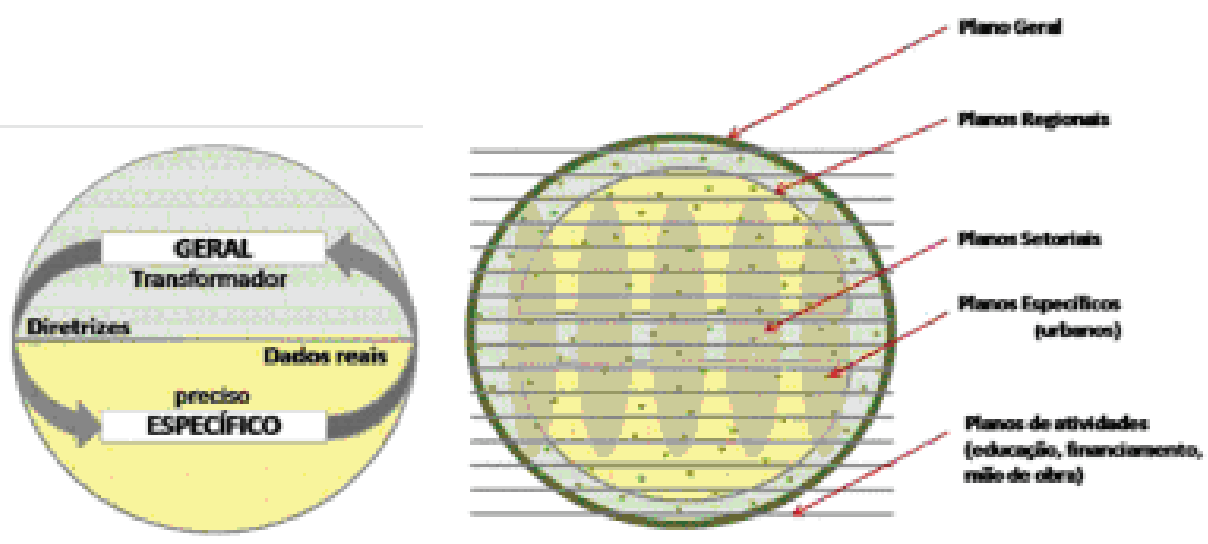

Os exemplos citados por Rômulo vão construindo uma história das agências e dos planos, narrada do ponto de vista do servidor público e revelando o leque de possibilidades que se apresentaram ao longo da história da nação, quase uma história das decisões do desenvolvimento brasileiro.

Para Rômulo, então seria mais do que a forma de apresentar os fatos, mas antes, a característica básica do tipo de desenvolvimento brasileiro. O que define como "um comportamento muito frequente no Brasil (...)", da ação planejadora do Estado, que constitui, em primeiro lugar, os agentes capazes de implementar os programas antes mesmo de sua criação (Almeida, 1975a, p. 9). O trecho abaixo é esclarecedor:

Bom, aí talvez haja implícita uma idéia que, vamos dizer, nós não explicitamos que eu me lembre na época, mas depois interpretamos a própria diretriz implícita que continha. Era a idéia de que numa estrutura econômica muito incipiente, inclusive desprovida de informações, o planejamento formal, além de ser politicamente oneroso naquela ocasião era também pouco eficiente. Então, o que nos parecia mais importante: estabelecer programas básicos, projetos de impacto e sobretudo agências capazes de operação dinâmica. Ainda que essas agências contivessem um risco, o risco de cada uma delas, como uma entidade autônoma, puxar sua política então isso representaria uma dificuldade de coordenação a posteriori. Mas desde que essas agências estivessem voltadas para atividades básicas de que o país era grandemente carente, nós considerávamos que valia o risco. (Almeida, 1990, p. 10),

Rômulo apresenta a história da criação dos agentes capacitados do desenvolvimento a partir de 1930, descrevendo como narrador e personagem, a saga da conquista do planejamento no país e a superação do espírito incondicional de "lealdade à livre empresa" herdada do primeiro período republicano. 
Apesar do interesse do percurso histórico traçado, será a partir da crítica ao regime militar que Rômulo apresentará sua forma de planejamento democrático, uma estratégia de enraizamento das estruturas do desenvolvimento para realizar seu projeto nacional. Rômulo compreende o período inicial da ditadura a partir da contradição entre o programa privatista e a contingência econômica que impeliu o Estado a um grande aumento percentual dos investimentos nas infraestruturas, atuando como uma das causas do crescimento acelerado do período. A outra causa seria a inércia dos agentes dinâmicos criados no período anterior, que continuaram atuando e somados a um novo e importante agente criado pelo "governo revolucionário"o Banco Nacional de Habitação - teria dado um impulso adicional ao ritmo do desenvolvimento que desembocou no "milagre econômico" (Almeida, 1975a, p. 23).

No I Plano Nacional de Desenvolvimento, Rômulo identifica, como objetivo principal, a competição internacional do país, portanto a "defesa da empresa privada nacional" acentuada sem a preocupação com a concentração econômica. O objetivo era "desenvolver um modelo brasileiro de capitalismo industrial e de capitalismo financeiro. Daí as fusões e aglomerados; a ideia de fazer grandes empresas, grandes estruturas. A ideia de desenvolver as exportações" (Almeida, 1975a, p. 26).

Em tal modelo, Rômulo aponta o retorno de uma "visão colonialista" da integração nacional por meio dos programas de transportes, com vistas à exportação, isto é, "como se estivéssemos voltando ao século XIX quando a estrada de ferro não buscava o Brasil ao Brasil, mas o Brasil ao exterior; cada hinterland ao seu porto; e o porto a Hamburgo ou Nova York." Cita, por exemplo, o Plano de Integração Nacional - PIN (1970), que destinou vultosos recursos para a criação de grandes vias como a transamazônica (Almeida, 1975a, p. 27).

O II Plano Nacional de Desenvolvimento (1974-1979), na opinião de Rômulo, representou avanços em relação ao primeiro, na integração nacional, também na inserção externa na economia mundial, no desenvolvimento social e promoção das indústrias de base e insumos. Não se pode esquecer, contudo, que a avaliação foi pouco menos de um ano depois de sua publicação. Rômulo reconhece no documento relativo a este plano as bases para a reversão do processo de crescimento heteronômo conduzido pelo regime militar. Menciona o enfrentamento mais concreto do desenvolvimento tecnológico, citando: i) os programas do Fundo de Desenvolvimento de Pesquisas do Estado de São Paulo; ii) a descentralização do desenvolvimento industrial; iii) o equacionamento da questão agrária; iv) o reconhecimento da necessidade de políticas distributivas como a atualização do salário mínimo; v) a política de desenvolvimento urbano geral com a instituição das regiões metropolitanas.

Rômulo questiona também, na mesma época, as condições que determinam a desigualdade do desenvolvimento regional. Utilizando conceitos de autores como 
François Perroux e Harvey S. Perloff, identifica os potenciais de desenvolvimento regional em função do tipo de atividade econômica e acesso aos insumos básicos e ao mercado de consumo.

Questiona a teoria de tendência natural ao equilíbrio espacial, isto é, que a distribuição espacial, uma vez atingido certo grau de complementaridade entre as regiões, tenderia a homogeneizar-se ao invés de continuar crescendo de modo concentrado. Para o autor, não há dúvida de que a tendência espontânea de localização das atividades econômicas leva a uma concentração espacial que só pode ser controlada a partir da interferência política.

Embora tenha consciência das consequências negativas da concentração urbana e necessidade de interferência do poder público em reação ao processo de intensa polarização, Rômulo não acredita no desenvolvimento regional em sentido oposto, isto é, a partir de uma rede urbana não concentrada composta por um conjunto articulado de cidades médias. Critica, inclusive, as ações do SERFHAU neste sentido.

Uma política regional é uma política necessariamente, de concentração concentrada. Essa é uma primeira indicação. Aviso aos navegantes. Quem sair disso, se arrasa, se afunda em termos de desenvolvimento regional. Uma política de desenvolvimento regional é uma política de polarização progressiva. Corrigindo, entretanto, a tendência a concentração interminável. Então, aí perdura o fator político, manejado com lucidez dessa tendência de concentração do processo. $O$ processo que for conduzido, em termos de dispersão, é um processo estéril (Almeida, 1975c, p. 10).

Para Rômulo, a questão mais importante é o desenvolvimento regional e a chave para isso seria a determinação das potencialidades dinâmicas em cada região. Segundo o autor, esta foi a principal dificuldade encontrada pela Sudene durante o período militar. Ao não determinar o tipo de indústria com "maior potencial de indução" e adotar uma política industrial muito abrangente, guiada pelo mercado e isenções fiscais exclusivamente, não conseguiu garantir em um curto espaço de tempo o desenvolvimento da região nordestina.

Estou, apenas, aqui, exibindo uma ilustração em torno do programa mais importante para o país. O programa que realmente é chave para o processo de integração nacional, não considerando integração em torno simplesmente, de estradas, de miragem milionária para ligar o deserto, quer dizer ligar o nada ao nada. Mas em termos de integração ao mercado nacional. Dar uma nova dimensão ao mercado nacional. Incorporando trinta milhões de brasileiros ao mercado nacional. Incorporando uma região com uma posição geográfica, extraordinariamente, positiva (Almeida, 1975c, p. 13). 
Mesmo tendo uma avaliação negativa da política territorial conduzida pelos militares, Rômulo não abandona sua missão de produtor do desenvolvimento. Critica a diretriz "descentralizadora" do SERFHAU e a falta de um planejamento geral articulado com as potencialidades regionais, mas diante das adversidades, sempre encontra um potencial não explorado capaz de superar as dificuldades apontadas. Assim, Rômulo renova suas expectativas "no país do futuro", ressaltando que a vantagem de um país novo é poder explorar as potencialidades locacionais de sua rede urbana, em função do planejamento do desenvolvimento futuro, o que não ocorre em países onde o sistema de cidades encontra-se já implantado.

Assim, ao vincular a questão das disparidades regionais ao mecanismo do planejamento integrado como forma de gerar novas potencialidades no território nacional, integrando-o de maneira efetiva, Rômulo foge da síndrome do localismo que tomaria conta do país nos anos 1980 e 1990. Em contrapartida, se ele sabe que no plano político "não pode haver solução cabal ao desajuste regional sem uma mudança político-social a nível nacional”, ele reconhece que, no plano econômico, não adianta atenuar o avanço da produtividade e do conteúdo tecnológico das regiões periféricas do país. A aposta no dualismo tecnológico está fadada ao fracasso e a inserção nordestina deve mostrar-se competitiva .

O técnico que assumira, no passado, uma "consciência nitidamente nacional e anti-regionalista" [sic], ou seja, "no momento de unir o país", faz-se suceder por um outro que defende uma "política lúcida de desconcentração, sem distributivismo espacial prematuro". Do contrário, "o movimento imperial interno inicial poderia levar a um país dual”, na concepção de Almeida (1985b, p. 4-6). O combate às disparidades regionais, em seu entender, não se faria com programas sociais compensatórios, mas com um planejamento democrático e descentralizado que reconhecesse a relevância dos processos econômicos históricos, os quais não são movidos estritamente pelas forças de mercado.

\section{Considerações finais}

Parece - como se procurou demonstrar a partir de um esforço de reinterpretação ancorado no olhar privilegiado de Rômulo Almeida -, uma simplificação excessiva, além de marcada pelo economicismo, a caracterização de nacional-desenvolvimentista corriqueiramente atribuída ao período 1930-1980.

Se a Revolução de 1930 mostrou-se fundamental para a ruptura com o molde econômico e social anterior e o Estado Novo permitiu que uma nova postura do Estado emergisse, sua forma autoritária não contribuía para que a sociedade aparecesse como partícipe desse esforço de autotransformação.

O "bom e velho desenvolvimentismo" - aqui representado pelo pensamento de Rômulo Almeida, um praxista, segundo sua própria acepção - originou-se de um 
consenso estruturado por um grupo de intelectuais orgânicos do aparelho estatal que buscou aliados junto a parcelas expressivas dos trabalhadores, das classes médias e dos empresários e exerceu forte impacto na definição dos rumos do desenvolvimento econômico do país durante o período 1946-1964.

O mote era o desenvolvimento nacional autônomo. Dizer que isso era ingenuidade e o capitalismo brasileiro teria de seguir por meio de "fugas para frente", por ser a estrutura de seu DNA, significa aceitar que os segmentos conservadores (tradicionais e modernos) teriam de vencer como se a história estivesse escrita de antemão.

Após o golpe de 1964, o Brasil, no máximo, e apenas em comparação com os vizinhos do Cone Sul - aos poucos convertidos aos ventos do neoliberalismo avant la lettre -, ingressa na era pós-desenvolvimentista. O milagre econômico e a síndrome do Brasil Potência tratariam de fazer crescer o mercado interno, com diversificação produtiva e ativismo estatal. Só miopia de economista pode chamar tal combinação de desenvolvimentista. Ao fim e ao cabo, o regime militar navegou no rastro de um processo que vinha de longe, fez algumas reformas para alavancar a acumulação de capital e tirou o povo da história.

As últimas duas décadas do século XX foram não desenvolvimentistas até a medula. Nos anos 1980, viveu-se o ápice do conjunturalismo na economia, apesar das mobilizações sociais e da conquista obtida com que a Constituição de 1988. A citada pauta, no entanto, vinda de baixo, não desembocou em nova perspectiva desenvolvimentista. Já, nos 1990, viveu-se a febre da abertura sem critérios. Era o tempo de desfazer-se do "desenvolvimentismo", ultrapassado pelo vendaval da globalização, como então se dizia.

Os antidesenvolvimentistas aproveitaram a crise da dívida externa para enfraquecer o potencial de negociação do país durante o lançamento do Plano Real. Um plano de estabilização econômica com reformas de base ao avesso. Se não tivessem sido interrompidos pela crise de 1999, o país não teria voltado a pronunciar o vocábulo desenvolvimento nas décadas seguintes. O mercado interno que eles desprezavam, voltou afoito como um trem desgovernado. Assim, ou ele avança mais uma vez concentrando renda e aprofundando desequilíbrios estruturais, ou logra-se inaugurar uma nova perspectiva desenvolvimentista.

Este artigo procurou lançar luz sobre como tais dilemas tão atuais foram vivenciados pelo servidor público, economista e pensador Rômulo Almeida, que ocupou cargos estratégicos de 1950 em diante e talvez tenha sido o último - dentre os grandes desenvolvimentistas de sua geração - a acreditar nas potencialidades nacionais, enfrentando com projetos, críticas embasadas e utopias os tecnocratas do governo militar. 
O legado de Rômulo remete os economistas, cientistas sociais, servidores públicos e representantes da sociedade civil à seguinte questão presente nos debates acadêmicos e midiáticos. Que significa ser desenvolvimentista hoje?

Significa pensar a nação com a mirada no horizonte para além da economia e os pés fincados na política e na sociedade. Significa transformar as estruturas internas, ao mesmo tempo em que se aproveitam as potencialidades da economia global em processo de reconfiguração profunda.

Em tal sentido, sem uma reflexão acerca da especificidade histórica e do atual enquadramento na nova divisão internacional do trabalho, como propor políticas econômicas, sociais, regionais, tecnológicas e de desenvolvimento?

Pode a "velha" tríade autoestima nacional, reflexão teórica autônoma e projeto de desenvolvimento com mobilização das forças sociais, em um contexto de ampliação dos espaços democráticos, ser recuperada em novas bases?

Para tanto, uma análise crítica do governo Lula faz-se necessária, sem olvidar que ele criou as condições para mirar no sentido da linha do horizonte. As desigualdades sociais e regionais continuam gritantes ou apenas mudaram de forma. O sistema produtivo dinamizou-se, mas continua refém das pressões competitivas externas ou apenas acompanha de forma adaptativa o movimento da demanda. O Estado recuperou a capacidade de formulação, mas continua ressentindo-se da excessiva fragmentação.

Em contrapartida, não há como negar o mercado interno robustecido, as instituições públicas eficientes em vários setores, a democracia em processo de consolidação, a sociedade civil ativa, a agricultura de grande porte capitalizada e competitiva, além da agricultura familiar com enorme potencial para expansão, a indústria ainda minimamente integrada e diversificada, as tecnologias avançadas em várias frentes energéticas e a política externa que logrou recuperar sua velha tradição, apostando na identidade Sul, sem se isolar do Norte. Ainda mais, já não é preciso gigantes como Rômulo, embora eles sirvam de farol.

Essas várias potencialidades apenas listadas - que não deixam de revelar suas facetas contraditórias - precisam estar conectadas em torno de um projeto nacional, enraizado no território, de modo a atender as diversas demandas das áreas rurais e urbanas.

O problema não é econômico. A ideologia deve fornecer o substrato às políticas que passam a desacreditar das velhas roupagens e estimular a imaginação criadora, mas a batalha final acontece no campo da estrutura de poder. Não existe, então, fórmula pronta para o desenvolvimento. 
Quem sabe se - sem que se perceba - já não se está prestes a ultrapassar a linha que separa a atual geração do pré-desenvolvimentismo? Isso quer dizer que ainda se tem muito chão pela frente se houver interesse realmente, por parte dos segmentos que compõem o tecido social da nação, de inaugurar um "novodesenvolvimentismo".

\section{Referências bibliográficas}

ALMEIDA, Aristeu Barreto de (Org.). Rômulo Almeida: construtor de sonhos. Salvador: Corecon/BA, 1995.

ALMEIDA, Rômulo. Curso de planejamento urbano. Salvador: Instituto de Arquitetos do Brasil (IAB). Acervo IRAE, aula 1 de set., 1975a. Mimeo.

- Curso de planejamento urbano. Instituto de Arquitetos do Brasil (IAB). Salvador: Instituto de Arquitetos do Brasil (IAB). Acervo IRAE, aula 2 de set., $1975 b$.

. Curso de planejamento urbano. Salvador: Instituto de Arquitetos do Brasil (IAB). Acervo IRAE, aula 5 de set., $1975 \mathrm{c}$.

- Reflexões sobre o desenvolvimento do Brasil. Discurso como Paraninfo, Faculdade Católica de Ciências Econômicas da Bahia. Salvador: acervo IRAE, partes II, III, IV e V, 1977. Mimeo.

- A castração. Artigo escrito para a Folha de São Paulo e Jornal da Bahia. Salvador: acervo IRAE, 9 fev., 1978. Mimeo.

. Na experiência universal de estratégia... Texto enviado ao Jornal do Brasil, 3 out. 1979. Salvador: acervo IRAE, 1979. Mimeo.

- Discurso ao Receber o Título de Doutor Honoris Causa da Universidade Federal do Ceará. Salvador: acervo IRAE, 14 set. 1982. Mimeo.

. Estrutura política periférica e capitalismo tardio. Teresópolis: ILPES. Salvador: acervo IRAE, abr. 1983. Mimeo.

- O Nordeste no segundo governo Vargas. Fortaleza: BNB, 1985a.

- Discurso de Posse como Diretor da Área Industrial do BNDES. Salvador: acervo IRAE, 1985b. Mimeo.

- Rômulo: voltado para o futuro. Fortaleza: Banco do Nordeste do Brasil / Associação dos Sociólogos do Estado da Bahia, 1986.

. Rômulo Almeida. Depoimento [1988]. Rio de Janeiro: CPDOC/

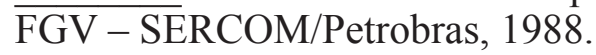


ALMEIDA, Rômulo. Rômulo Almeida. Depoimento [1980]. Rio de Janeiro: FGV/CPDOC - História Oral, 1990.

Política econômica no Segundo Governo Vargas. In: SZMRECSÁNYI, T.; GRANZIERA, R. (Org.). Getúlio Vargas \& a economia contemporânea. Campinas: Editora da Unicamp, 2004.

Depoimento [1982]. Memórias do Desenvolvimento, Rio de Janeiro, Centro Internacional Celso Furtado de Políticas para o Desenvolvimento, ano 3, n. 3, out. 2007. s.d. a. Mimeo.

. Uma página de memórias sobre Aratú. Salvador: acervo IRAE, . As opções do economista. Salvador: acervo IRAE, mimeo, s.d. b. Mimeo. s.d. c. Mimeo.

Nacionalismo e capitais estrangeiros. Salvador, acervo IRAE, . Mito e realidade do empresário nacional I. Salvador: acervo

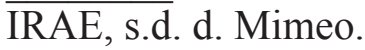

BIELSCHOWSKY, Ricardo. Pensamento econômico brasileiro: o ciclo ideológico do desenvolvimentismo. 2. ed. Rio de Janeiro: Contraponto, 1995.

BONDUKI, Nabil. Origens da habitação social no Brasil: arquitetura moderna, lei do inquilinato e difusão da casa própria. São Paulo: Estação Liberdade, 1998.

CAMPOS, Roberto. Economia, planejamento e nacionalismo. Rio de Janeiro: APEC Editora, 1963.

. A lanterna na popa: Memórias. Rio de Janeiro: Topbooks, 1994.

COUTINHO, Carlos Nelson. Cultura e sociedade no Brasil: ensaios sobre idéias e formas. 4. ed. São Paulo: Expressão Popular, 2011.

DRAIBE, Sônia. Rumos e metamorfoses. Rio de Janeiro: Paz e Terra, 1985.

FERNANDES, Florestan. (1974). A revolução burguesa no Brasil: ensaio de interpretação sociológica. 3. ed. Rio de Janeiro: Editora Guanabara, 1987.

FURTADO, Celso. O mito do desenvolvimento econômico. 4. ed. Rio de Janeiro: Paz e Terra, 1974.

Pequena introdução ao desenvolvimento: um enfoque interdisciplinar. Rio de Janeiro: Companhia Editora Nacional, 1980.

. Depoimento [1977]. In: SOLA, Lourdes. Idéias econômicas, decisões políticas. São Paulo: Edusp, 1998a. Entrevista concedida a Lourdes Sola. 
FURTADO, Celso. O capitalismo global. São Paulo: Paz e Terra, 1998b.

GOMES, Angela de Castro. Novas elites burocráticas. In: GOMES, Angela de Castro (Coord.). Engenheiros e economistas: novas elites burocráticas. Rio de Janeiro: Editora da Fundação Getúlio Vargas, 1994, p.1-12.

2005. . A invenção do trabalhismo. 3. ed. Rio de Janeiro: Editora da FGV,

IGLESIAS, Francisco. Trajetória política do Brasil: 1500-1964. São Paulo: Companhia das Letras, 1993.

JAGUARIBE, Helio. O nacionalismo na atualidade brasileira. Rio de Janeiro: ISEB, 1958.

. Jornal do Brasil, 28 nov. 1988. In: ALMEIDA, Aristeu Barreto de (Org.). Rômulo Almeida: construtor de sonhos. Salvador: Corecon/BA, 1995, p. 77.

LATINI, Sidney. A implantação da indústria automobilística no Brasil: da substituição de importações à globalização passiva. São Paulo: Alaúde Editorial, 2007.

LESSA, Carlos. Depoimento [25 maio 2011]. In: BARBOSA, Alexandre de Freitas. Rômulo Almeida e as bases econômicas e institucionais para o desenvolvimento da nação. Programa Cátedras Ipea/Capes para o Desenvolvimento. São Paulo: Relatório de Pesquisa, 2012. Entrevista concedida ao Grupo de Pesquisa O Pensamento Nacionalista no Século XX/ IEB USP.

OLIVEIRA, Francisco. Depoimento [3 abr. 2011]. In: BARBOSA, Alexandre de Freitas. Rômulo Almeida e as bases econômicas e institucionais para o desenvolvimento da nação. Programa Cátedras Ipea/Capes para o Desenvolvimento. São Paulo: Relatório de Pesquisa, 2012. Entrevista concedida ao Grupo de Pesquisa O Pensamento Nacionalista no Século XX/ IEB USP.

PEDRÃO, Francisco. Depoimento [5 ago. 2011]. In: BARBOSA, Alexandre de Freitas. Rômulo Almeida e as bases econômicas e institucionais para o desenvolvimento da nação. Programa Cátedras Ipea/Capes para o Desenvolvimento. São Paulo: Relatório de Pesquisa, 2012. Entrevista concedida ao Grupo de Pesquisa O Pensamento Nacionalista no Século XX/ IEB USP.

PEDRÃO, Fernando. Rômulo Almeida: pensar (e viver) o futuro. In: ALMEIDA, Aristeu Barreto de (Org.). Rômulo Almeida: construtor de sonhos. Salvador: Corecon/BA, 1995.

PENNA, Lincoln de Abreu. República brasileira. Rio de Janeiro: Nova Fronteira, 1999. 
PEREIRA, Jesus Soares. O homem e sua ficha. Rio de Janeiro: Civilização Brasileira, 1988.

PRADO JR., Caio. A revolução brasileira. São Paulo: Brasiliense, 1966.

RANGEL, Ignacio (1985). Economia: milagre e anti-milagre. Rio de Janeiro: Contraponto, 2005. v. 1.

RISÉRIO, Antônio. Uma história da cidade da Bahia. 2. ed. Rio de Janeiro: Versal Editores, 2004.

SANTOS, Wanderley Guilherme. O ex-Leviatã brasileiro. Rio de Janeiro: Civilização Brasileira, 2006.

SOLA, Lourdes. Idéias econômicas, decisões políticas. São Paulo: Edusp, 1998.

VIANNA, Luiz Werneck. A revolução passiva: iberismo e americanismo no Brasil. 2. ed. Rio de Janeiro: Revan, 2004. 